
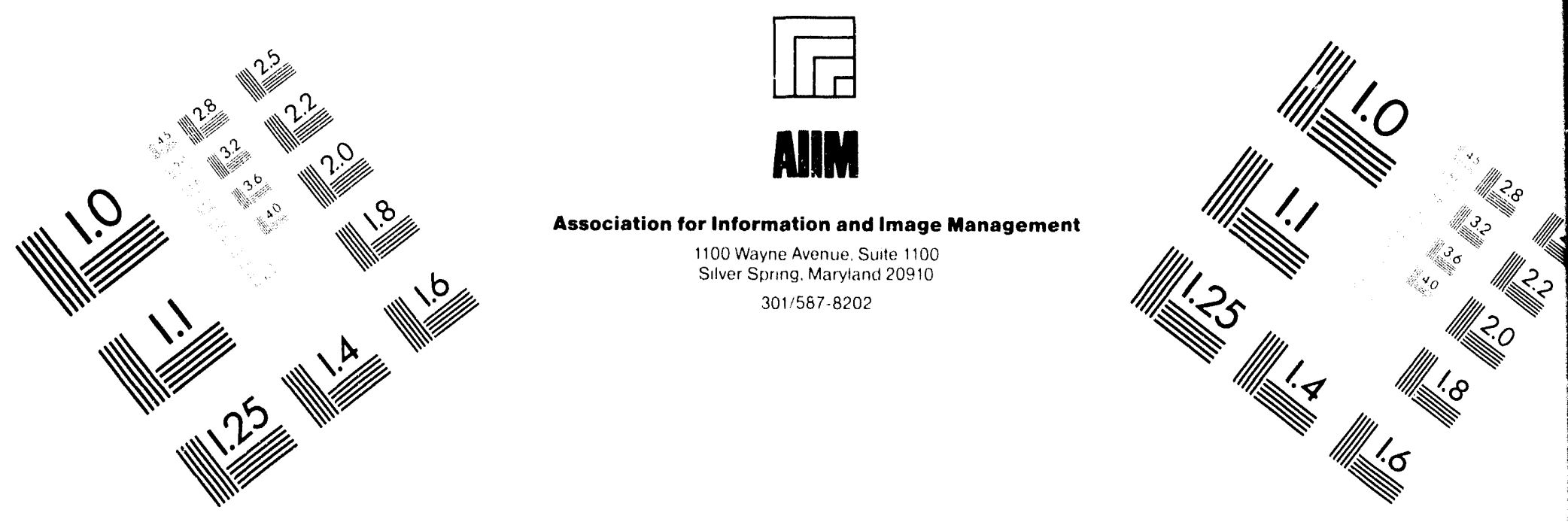

Centimeter

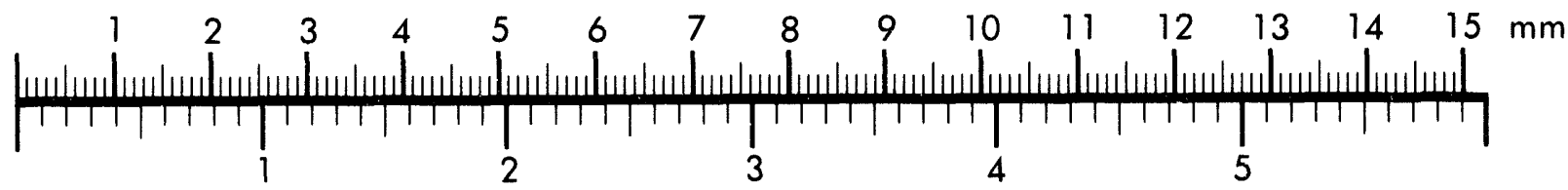
Inches
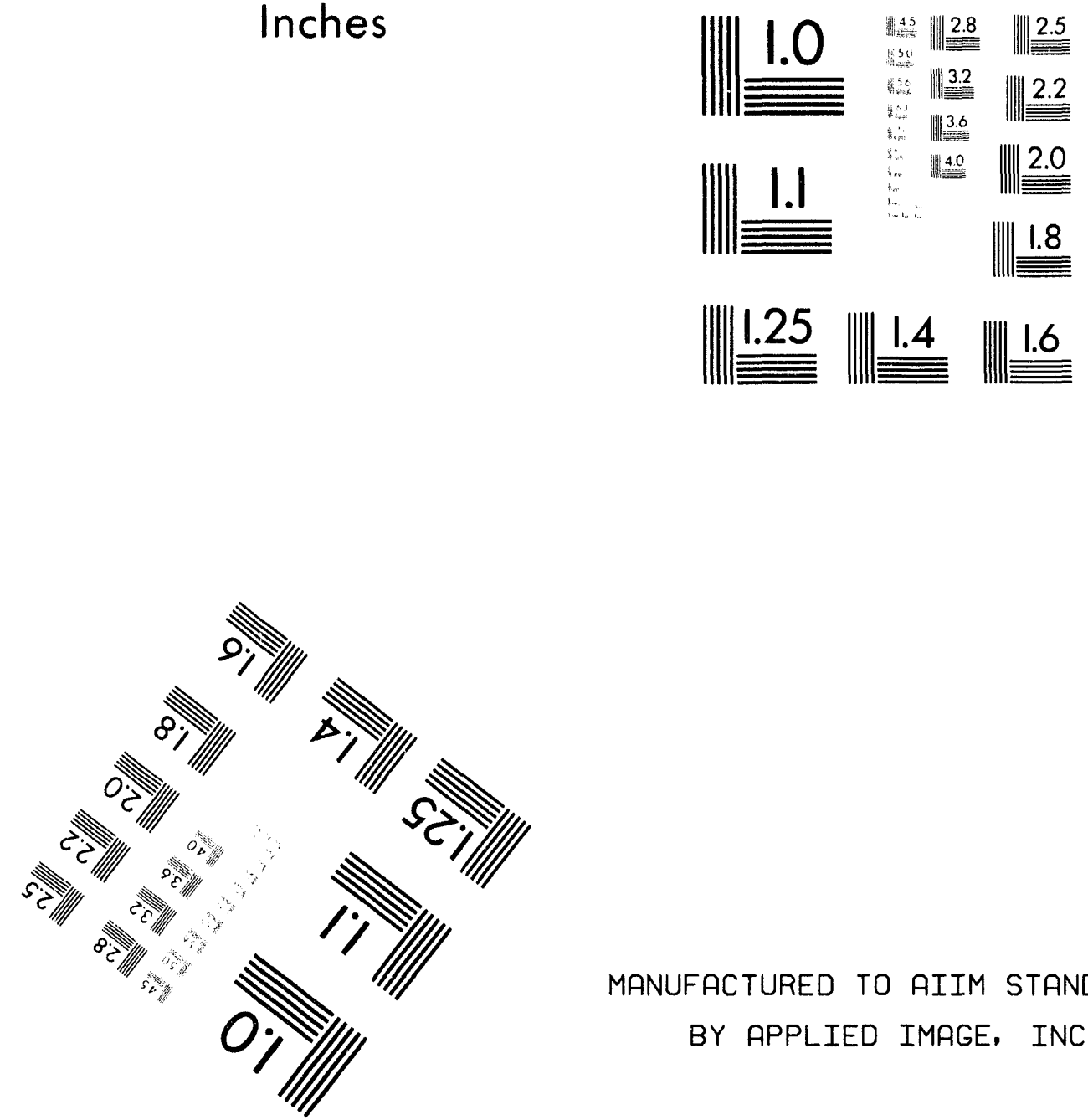

MANUFACTURED TO AIIM STANDARDS

BY APPLIED IMAGE, INC.

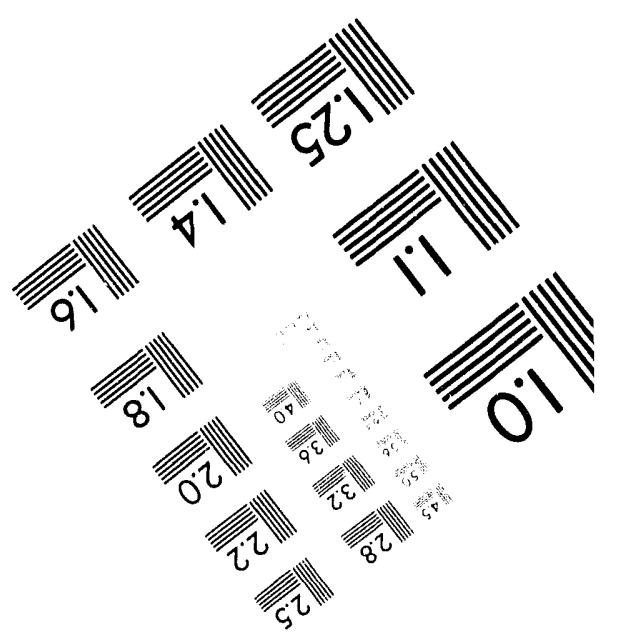



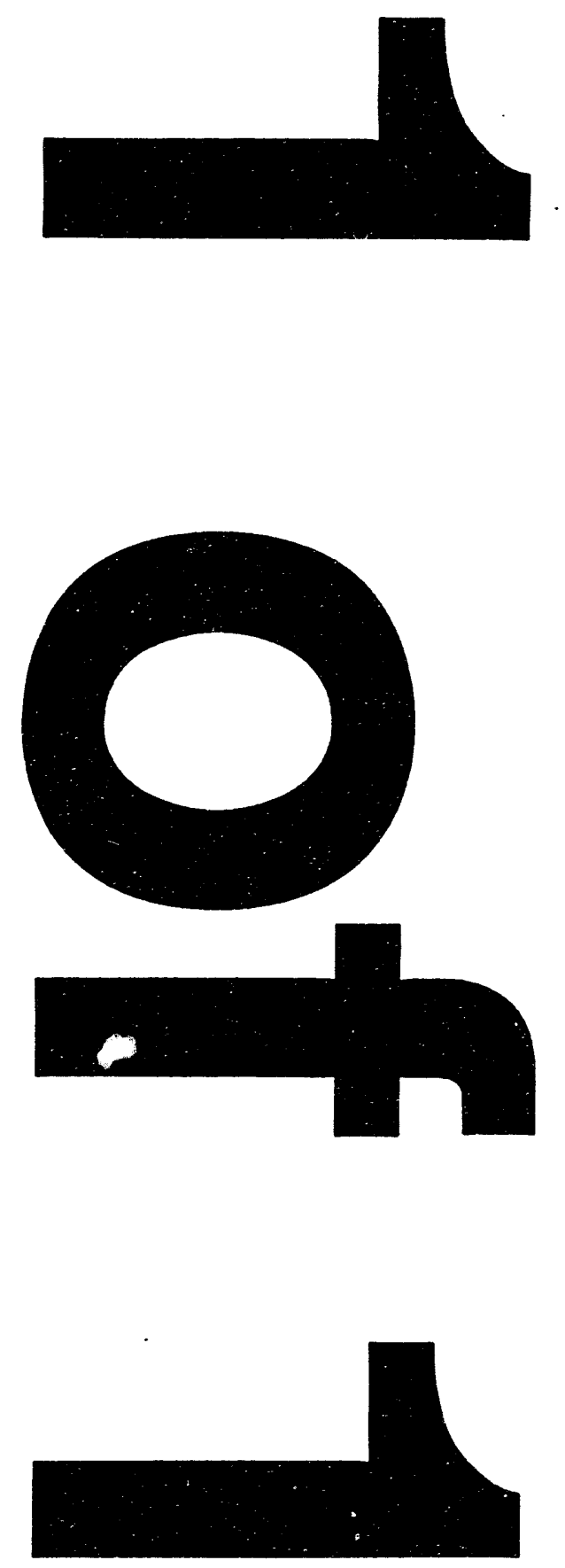


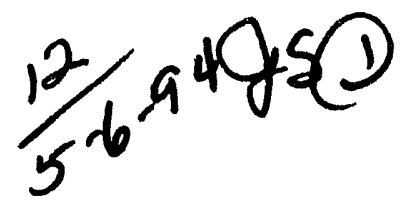

UCRL-ID-116129

\title{
New Observations of Infiltration through Fractured Alluvium in Yucca Flat, Nevada Test Site: A Preiiminary Field Investigation
}

a

\author{
Cindy S. Kao
}

Department of Civil Engineering University of California, Berkeley

David K. Smith

Nuclear Chemistry Division

Lawrence Livermore National Laboratory

William B. McKinnis*

Lawrence Livermore National Laboratory

Niercury, Nevada

*Retired

February 1994

This is an informal report intended primarily for internal or limited external distribution. The opinions and conclusions stated are those of the author and may or may not be those of the Laboratory.

- Work performed under the auspices of the U.S. Department of Energy by the

- Lawrence Livermore National Laboratory under Contract W-7405-Eng-48. 


\section{DISCLAIMER}

This document was prepared as an account of work sponsored by an agency of the United States Government. Neither the United States Government nor the University of Catifornia nor any of their employees, makes any warranty, express or implied, or assumes any legal liability or responsibility for the accuracy, completeness, or usefulness of any information, apparatus, product, or process disclosed, or represents that its use would not infringe privately owned rights. Reference herein to any specific commercial products, process, or service by trade name, trademark, manufacturer, or otherwise, does not necessarily constitute or imply its endorsement, recommendation, or favoring by the United States Government or the University of California. The views and opinions of authors expressed herein do not necessarily state or reflect those of the United States Government or the University of California, and shall not be used for advertising or product endorsement purposes.

This report has been reproduced directly from the best available copy.

A vailable to DOE and DOE contractors from the Office of Scientific and Technical Information

P.O. Box 62, Oak Ridge, TN 37831

Prices a vailable from (615) 576-8401, FTS 626-8401

Available to the public from the

National Technical Information Service

U.S. Department of Commerce

5285 Port Royal Rd.

Springfield, VA 22161 


\section{ABSTRACT}

Regional tectonics coupled with the subsurface detonation of nuclear explosives has caused widespread fracturing of the alluvium of Yucca Flat. Fractures deeper than 30 meters have been observed in boreholes. Some of these fractures are large enough to capture significant amounts of runoff during storm events. Evidence of stream capture by fractures and observations of runoff flowing into open fractures give qualitative evidence of infiltration to depths greater than several meters and possibly to the saturated zone. Our field observations contradict the assumption that little infiltration occurs on Yucca Flat. The larger, hydrologically important fractures are associated with geologic faults or the regional stress field. Additional field studies are needed to investigate the impact of fractures on the transport of contaminants.

\section{INTRODUCTION}

The alluvium of Yucca Flat, a closed intermontane basin within the Nevada Test Site, Nye County, Nevada, has been extensively fractured by both regional tectonics and by the subsurface detonation of nuclear explosives. The surface trace of fractures has been mapped by the United States Geological Survey (USGS), but data on their subsurface expression is limited. Past studies of infiltration in this region have focused on unfractured alluvium while the potential for recharge through fractures has not been seriously investigated. It is generally believed that little if any deep infiltration or recharge occurs directly through the alluvial soils of these basins, except in areas such as craters and playas that experience ponding, where the downwards flux can be several orders of magnitude greater than in undisturbed areas (Tyler, 1987). However, past and recent observations of fractures exposed at the ground surface and in trenches and boreholes suggest that deep infiltration occurs through fractures in Yucca Flat to a depth of at least several meters and possibly to the water table. As such, fractures may act as pathways for accelerated migration of surface and subsurface contaminants. Of particular concern is the potential for groundwater contamination by runoff carrying radionuclides or other hazardous materials. This report summarizes the current understanding of fracturing in alluvial soils, documents past and recent field observations of fractures in Yucca Flat, describes possible infiltration behavior, and offers recommendations for future field work.

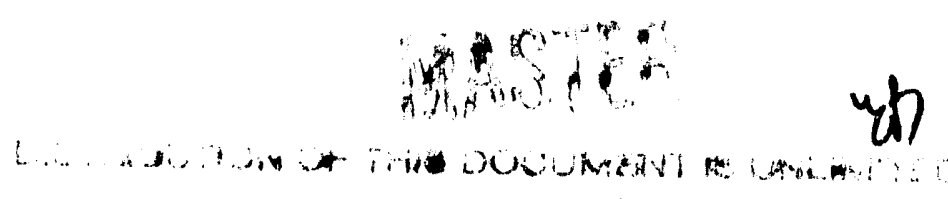




\section{GEOLOGY}

\section{The Nevada Test Site}

The Nevada Test Site (NTS) is located in the southern Great Basin, Nevada (Figure 1). NTS is north-west of, and may possibly overlap, the Las Vegas Valley-Walker Lane Shear zone, a transcurrent fault system with 40 kilometers of right lateral movement. Upper Precambrian and Paleozoic sedimentary rocks totaling 12 kilnmeters in thickness form the basement of the NTS and outcrop in north-northeast trending ranges. Tertiary and Quaternary volcanic rocks, predominantly ash flow tuffs of rhyolitic composition, overlie the basement rocks. Basins filled with late Tertiary and Quaternary alluvium and colluvium cover about $30 \%$ of the region (Ekren, 1968). The NTS underwent several periods of compressive crustal deformation during the Paleozoic and Mesozoic eras, then changed to regional extension during the late Eocene epoch, resulting in east-dipping normal and strike slip faulting (Knauss, 1981; Gillson, 1993). Crustal extension occurred in an east northeast direction from Oligocene to mid-Miocene epochs. This was followed by a second phase of extension in a west-northwest direction that is still occurring. The rate of extension in the last 20 million years has slowed from $2-3 \mathrm{~cm} /$ year to $1 \mathrm{~cm} /$ year (Carr, 1974; Gillson, 1993).

Two periods of normal faulting created an older set of northwest and northeast trending normal faults and a younger set of faults that strike north-south. The older fault set began forming 17 million years ago and was well developed by the mid Miocene epoch. The younger

set began forming 14 million years ago and is still developing; it controls the north-south orientation of the present day basins and ranges

(Knauss, 1981). Three northeast trending major thrust faulis at the NTS push the upper Precambrian and lower Paleozoic rocks to the southeast over the middle and upper Paleozoic sequence. These are the Mine mountain thrust zone, the CP-Tippinip thrust zone, and the Spotted Range thrust zone, shown in Figure 2 (Barnes and Poole, 1968; Gillson, 1993; Sweeney, 1983).

\section{Yucca Flat}

Yucca Flat was formed during the late Miocene extensional faulting. The basin strikes north for more than 30 kilometers with a maximum width of almost 16 kilometers. The margins of the flat are gently step faulted while highly faulted grabens exist near the center. Late Precambrian and Paleozoic carbonate and clastic rocks form the basement and outcrop in the surrounding mountains (Carr, 1974). The 
valley fill consists mainly of Recent, Quaternary, and Tertiary alluvium composed of beds of moderately consolidated to unconsolidated detrital material transported from the surrounding highlands. Particle sizes of the alluvium range from clay to boulders up to 5 meters in diameter but are dominated by sand and gravel. Cobble and boulder layers are common in the upper 300 meters in northern Yucca Flat. Less than $10 \%$ clay is present throughout most of the alluvium (Spengler and Glanzman, 1980; Williams et al., 1963). The geologic history of Yucca Flat incorporates folding and faulting of older Tertiary rocks with subsequent silicic volcanism and deposition of alluvium into the structural basins.

North-south striking normal faults cut across the basement rocks of Yucca Flat. The two major faults are Yucca and Carpetbag Faults (Figure 3), which belong to the younger period of normal faulting that began 14 million years ago and is still continuing. Yucca Fault is a north trending, east dipping $\left(75^{\circ} \mathrm{E}\right)$ normal fault that stretches from Yucca Lake to Butte Fault. It is $34 \mathrm{~km}$ long and forms an east facing scarp up to 12 meters high at its northern end but decreases in surface expression as it approaches Yucca Lake to the south. The Carpetbag Fault is also a north trending, east-dipping normal fault mapped west of the Yucca Fault. It approaches Yucca Fault at the Yucca-Frenchman flexure and may extend the length of the valley, possibly joining the south-west end of the Boundary Fault. The average dip of the fault at the surface is $70^{\circ}$ and probably decreases with depth. Age dating of secondary carbonates found in the faults indicates that the last natural movement on Yucca Fault was less than 35,000 years ago, while the last natural movement on the Carpetbag Fault was between 37,000 and 93,000 years ago (Knauss, 1981).

\section{HYDROLOGY}

Six major hydrostratigraphic units can be defined in the NTS area and are listed in Table 1, along with available transmissivities and permeabilities. From oldest to youngest, these units are the lower confining unit, the lower carbonate aquifer, the Eleana confining unit, the upper carbonate aquifer, the volcanic aquifers and confining units, and the alluvial aquifer (Winograd and Thordarson, 1975). The highly transmissive Paleozoic carbonate rocks constitute the aquifer system of regional importance. Both the lower confining unit and the lower carbonate aquifer extend beneath almost the entire Nevada Test Site. The Eleana Formation is restricted to the north central NTS, and the saturated Tertiary volcanics are located in the western sections of the study area, while saturated alluvial materials that influence groundwater migration are present in central and southern Yucca Flat, Frenchman 
Flat, Jackass Flats, and the Amargosa Desert (DOE, 1993). Faults and other structural features form barriers to groundwater flow that compartmentalize the groundwater system into distinct but interconnected cells (Winograd and Thordarson, 1968).

The regional groundwater-flow system consists of three subbasins. From east to west, these are the Ash Meadows, Alkali Flat-Furnace Creek Ranch, and Oasis Valley subbasins. Groundwater flows from northern and eastern recharge areas towards discharge areas at Ash Meadows and Death Valley in the southwest. Groundwater may flow between the Alkali Flat, Furnace Creek Ranch, and Ash Meadows subbasins across the Eleana Formation. Aquifer properties, structural features, and the major recharge and discharge areas of each subbasin control the direction and rate of groundwater migration (DOE, 1993).

Yucca Flat is located within the Ash Meadows subbasin. Water table depths range from 160 to 580 meters below the ground surface. The great depth to water results from drainage of groundwater from the alluvial and older Cenozoic aquifers into the underlying and surrounding lower carbonate aquifer; the water is semiperched and moves downward from the younger into the older aquifers (Winograd and Thordarson, 1975). The hydrologic units of importance include the alluvial, volcanic, and carbonate aquifers and the volcanic and clastic confining units. Downward hydraulic gradients predominate within the tuff aquitard and horizontal gradients exist within the volcanic units, indicating lateral flow towards central Yucca and Frenchman Flats prior to vertical transmission (DOE, 1993).

Drinking and industrial water supply wells at the NTS draw water from the carbonate, volcanic and valley-fill aquifers, while private and public water supply wells south of the NTS are completed in the valley fill aquifer (DOE, 1993)

\section{FRACTURED ALLUVIUM IN YUCCA FLAT}

From 1952 to 1992, approximately 500 nuclear tests were fired on or beneath Yucca Flat; testing has extensively fractured much of the alluvium and basement. Figure 4 gives the location of underground nuclear tests performed through 1990. While the surface expression of fractures is readily identified and mapped by the USGS, subsurface investigations are expensive and time consuming. As a result, few subsurface investigations have been carried out expressly to study fractured alluvium. Past concern has focused on the possibility that fractures are zones of weakness that vent to the surface during 
underground testing; they have not been considered in the context of recharge to the deep subsurface. Consequently, little is known about the three-dimensional geometry of the fractures or their ability to transmit water.

The formation of fractures in Yucca Flat is the result of both underground nuclear explosions and regional tectonics. The following mechanisms have been proposed:

1. Cratering

Circumferential fractures form concentric rings around craters caused by subsurface explosions. These are not influenced by regional tectonics.

2. Regional stress field

The regional stress field of the NTS is anisotropic with the minimum principai stress direction approximately $\mathrm{N} 50^{\circ} \mathrm{W}$ (Carr, 1974; Gillson, 1993). The stress field causes regional extension of the NTS in this direction with associated fracturing of the alluvium and underlying bedrock (Carr, 1974). Fractures form when subsurface explosives create additional stress along northeast striking planes that are already weakened by the regional stress field. These fractures are probably but not necessarily associated with corresponding fractures in bedrock.

3. Bedrock joints

Fractures has been observed to align preferentially in the direction of bedrock joints (Barosh, 1968; Susan Freeman, Los Alamos National Laboratory, personal communication, 1993). The joints are typically parallel to associated northeast trending fault sets, but the close spacing of the fracture sets that are aligned with joints indicate that the joints rather than the associated faults control the fracturing of the alluvium. The fracturing could be caused by differential movement along the joints in response to subsurface explosions. Explosions detonated in alluvium do not produce preferred fracture orientations, while explosions detonated in tuff and sedimentary rock have consistently produce preferential fracturing. The degree of preferred orientation varies inversely with the height above 
the bedrock-alluvium contact (Barosh, 1968).

4. Stress release along faults

The stress caused by the detonation of underground explosives combines with the existing regional stress field to increase the displacing force acting along the fault, while the vibrations produced by the explosions may simultaneously reduce the frictional force resisting movement. The combination of these two mechanisms causes fracturing and displacements along the fault in response to underground explosions (Dickey, 1968). The resulting fracture sets trend north-south and probably extend into bedrock. The two major faults of Yucca Flat, the Yucca and Carpetbag Faults, control the major fracture sets.

5. Differential compaction

Differential settlement caused by relative compaction of the alluvium by underground explosions, has been proposed as another fracturing mechanism along faults. Subsurface detonations could cause compaction of the soil on the side of the fracture in which the explosion occurred, while the soil on the other side will remain relatively undisturbed. This would result in displacements along the fault that would propagate to the surface as fractures. However, explosions near Yucca fault always resulted in displacements that were relatively down on the east, even when the explosion occurred on the west side of the fault, and the compaction effects were not seen to be concentric around the explosion site, as would be expected. These observations tend to invalidate this hypothesis (Barosh, 1968).

\section{FIELD OBSERVATIONS OF FRACTURES}

Past investigations of fractures involve trenching across the Carpetbag and Yucca Faults (Wagoner, 1980; Carr, 1965), field checks of shot-induced faults (Barosh, 1968; Dickey 1968), and surface mapping of fractures. One hydrologic study was performed on a fracture in Yucca Lake (Doty and Rush, 1985). In addition, fractures encountered during fieldwork have been recorded in memos, some of which are summarized in Table 2 (see McKinnis and Kao, 1993). The memos are often 
sketchy, but they provide some information on fracture dimensions as well as an indication of their dynamic nature and ability to take water. Incidents were reported describing fractures that opened unexpectedly (U2dw) and drained ponded water or accepted runoff (U2ef reserve pit; U2gf). Almost all memo descriptions were made while drilling emplacement or exploratory holes for underground tests.

Recent field investigations were performed during July and August of 1993 to locate current zones of fracturing that are recharging the subsurface. Methods of identification were limited to visual observation of fractures open at the surface or exposed in trenches. Asrial photographs of the Carpetbag Fault system taken on 3/30/83 (scales $1: 12000$ and 1:4800) and composite fracture maps compiled by the USGS, Lawrence Livermore National Laboratory (LLNL), Los Alamos National Laboratory (LANL), and Fenix and Scisson were utilized to target fractured ground. Because of time constraints, only selected regions of Yucca Flat were investigated. The following sections describe the information obtained from these past and recent field investigations. Fractures are divided into three categories: circumferential fractures associated with cratering, northeast trending linear fractures controlled by bedrock joints and the regional stress field; and fractures controlled by faults.

\section{Circumferential Fractures}

Recent field observations showed circumferential fractures to be small at the surface without accepting much drainage. However, past observations show that these fractures reach substantial dimensions; Table 2 lists several investigations of circumferential fractures that extended up to 23 meters in depth.

\section{Linear Fractures}

Most linear fractures trend northeast and several have been seen to extend to greater than 30 meters in depth, as recorded in Table 2. A well defined set of this type of fracture cuts across Rainier Mesa Road near U2gf; these fractures are currently open and intercepting large quantities of runoff. Northeast of the road, the fractures are deep with steep vertical walls and widths of up to approximately $30 \mathrm{~cm}$. The storm induced fracture of August, 1988, listed in Table 2 and shown in Figure 5 , is part of this system; it opened to a width of $30 \mathrm{~cm}$ and split Rainier Mesa Road while accepting large quantities of runoff (McKinnis, personal observation). A similar set of northeast trending fractures west of U2ds are smaller. Vertical offsets of up to $30 \mathrm{~cm}$ can be measured from one 
side of a crack to another. There appears to be less drainage to these fractures, although signs of infiltration are evident.

Three fractures recently found near the U8a fault illustrate the potentially large dimensions of these features. The deepest fracture intersects the U8a fault at its northern extreme and is about a meter wide and appears to extend below a depth of 8 meters with no obvious signs of infiltration. Two other east-west trending cracks located between U8a and U8d are open but do not appear to intercept any drainage pathways. One of these appears to have recently opened, probably within the last year, as indicated by the lack of vegetation along freshly carved fracture walls. This fracture reaches a width of $60 \mathrm{~cm}$ and visibly extends below a depth of about 6 meters. The other is smaller and filled with sediment.

The most intensively studied linear fracture is the northeast trending Yucca Lake fracture, which appeared in 1969, stretching for about a mile across the lake, and rapidly drained the ponded surface water. The high rate of infiltration indicated that the fracture extended through the playa deposits into the alluvium and possibly into bedrock. Concern that the drained water was directly recharging the Paleozoic carbonate aquifer system at depth prompted the USGS to build a berm with ten Parshall flumes around the fracture to measure inflow; from November of 1974 to August of 1977, an estimated 142 thousand cubic meters of water flowed into the fracture (Doty and Rush, 1985).

Currently, most of the fracture is sealed, but along its northeasterly extension, two collapse sinks several meters in both diameter and depth were discovered by W. B. McKinnis before 1984 and are still present today. The sinks indicate that this portion of the fracture is currently recharging the subsurface. Figure 6 shows one of the sinks along the northeast strike of the fracture.

Three earlier northeast trending fractures opened across Yucca Lake, as shown in Figure 7; two opened before 1950 and one opened in 1960. These earlier fractures were sealed at the time that the 1969 fracture opened along the southern end of the lake. Carr (1974) identifies four other nearby playas, shown in Figure 8 , that contain similar fractures. He points out that nearly all the fractures in the playas of the NTS strike northeast, regardless of playa shape, and that large quantities of water flow into the cracks when they are new, suggesting that they possibly intersect bedrock. Carr (1974) describes the fractures on Yucca Lake as possibly being conjugate shears and extension cracks of the Yucca-Frenchman flexure that have formed as a result of extension of the entire Test Site in the direction of minimum principal stress. 
Faults

Faults typically show up as large fractures at ground surface and are the deepest and most extensive of the three types of fractures. Faults that experience large displacements likely extend into bedrock, forming pathways between the surface and groundwater.

Carpetbag Fault System

Among the fractures in Yucca Flat, the Carpetbag Fault system shows the most conspicuous evidence of recharge. The detonation of the Carpetbag event (U2dg) in December of 1970 triggered the formation of the 2500 meter long fault scarp paralleled on the east by a 1525 meter long antithetic in the north-central part of Yucca Flat, as shown in Figure 9 (Garcia and Sharps, 1986). The two scarps form a north-south shallow graben with a maximum depth of 5 meters. The fault has apparently been open and accepting runoff since the formation of the scarp.

Dense arrays of fractures running parallel to the base of each scarp were observed several years after the appearance of the fault scaip (McKinnis, personal observation). The base of the main fault scarp is currently deeply eroded by runoff while the graben is dissected and densely fractured, as illustrated in Figure 10. Many of the fractures are about half a meter wide and half a meter deep while others appear to have once been large but have now been sealed with sediment. In some cases, open fractures have eroded up to a meter or more in width and have filled with soft sediment below a meter depth. Several large collapse sinks were found in July 1993 along a fracture at the southern end of the main fault scarp. These are similar to but smaller than those appearing along the 1969 Yucca Lake crack at the edge of the lake bed.

Yucca Fault

Barosh (1968) reports that large fractures formed in the alluvium along Yucca Fault during underground nuclear testing and that no fractures were noted prior to testing. He describes fractures that formed after the detonation of an intermediate yield nuclear explosion detonated 670 meters from the fault as forming an en-echelon pattern along the fault with widths up to $20 \mathrm{~cm}$ wide and a meter deep, with displacements up to $76 \mathrm{~cm}$. Slumps and gravity grabens formed adjacent to the larger fractures. These fractures have filled in over the past decades and can no longer be seen; however, small fractures along the fault scarp currently accept minor amounts of recharge in Area 7. 
U2cm, U8a, and U8d Faults

Open fractures are currently present at the base of the $U 2 \mathrm{~cm}$ fault, along the southern portion of the U8a fault, and along the U8d fault. Drainage paths leading to these fractures and the eroded expression of the fractures indicate that recharge occurs in these regions.

Trenches

A number of trenches have been dug across the Carpetbag Fault by the USGS and LLNL. Two were bulldozed near the middle of the fault scarp, five across fault ramps near emplacement hole U2fe (Wayoner, 1980), and five north of Road 2-04 (Area 2) along the northsouth trace of the scarp. The trenches varied from 1.2 to 3.5 meters deep and revealed the vertical extension of the fractures beneath the surface. Fractures running along the surface of the ground that were intersected by the trenches were consistently seen to extend vertically down the trench walls, sometimes as small fractures millimeters to centimeters wide, as large fractures that have been filled with sediment of varying degrees of induration, and as open fractures with separations of up to $10 \mathrm{~cm}$. Caliche was found in fractures along the walls of several trenches, most conspicuously in a trench located near the scarp center (Figure 11).

Two trenches were dug across Yucca Fault in 1964 under the supervision of the USGS to study explosion produced and natural fractures and faults. Fractures were seen to propagate along the entire vertical height of the trench walls, and a 5 to $40 \mathrm{~cm}$ separation was measured along the Yucca Fault fracture. Roots were found up to a depth of 6 meters within the fractures; an estimate of the rate of root growth suggested that the cracks first formed in or before 1954 or 1955 (Carr, 1965).

\section{Other Areas}

In addition to the regions described above, the following areas were recently investigated: the Area 9 fault, the U10an fault and vicinity, the fracture between U4ah and U4ar, the region between Rainier Mesa Road and $\cup 4 \mathrm{e}$, and selected locations in eastern Area 7. None of these areas had fractures of hydrologic significance. Most of the fractures investigated in eastern Area 7 that were mapped by the USGS are no longer visible. 


\section{EVIDENCE OF INFILTRATION}

The relationship between runoff, infiltration and fracture size and formation was clearly seen throughout our field investigations. Stream channels tend to end or become less pronounced after interception by a fracture, and the fracture becomes deeper and more pronounced at the point of recharge. One example of this is illustrated by a stream channel that runs across the middle of the Carpetbag Fault scarp. Most of the drainage was captured by the fault, and the fault was deeply eroded and widened in the area of recharge. The portion of the stream that crossed the fault flowed across the graben and into the fractures at the base of the antithetic. Apparently no runoff from this drainage escaped the fault system.

A fracture along the Carpetbag Fault trace intercepted by a trench north of Road 2-04 dramatically illustrates the dynamic nature of fracture dimension and the influence of drainage-induced erosion. In early summer of 1992, the crack was small and apparently hydrologically insignificant. The following year, a stream channel was found to end in the ditch, and the fracture had been opened to approximately a meter wide and about two meters deep, filled below that depth with soft, unconsolidated sediment (Figure 12). This reactivated section currently extends along the former trace of the crack for at least $\mathbf{5 0}$ meters before ending; the crack then abruptly continues on with mild surface expression. The trench acted as a collection point where runoff could concentrate and erode the fracture open. Two other fractures that are intercepted by trenches in this region show similar behavior.

These, in addition to the other numerous conductive fractures observed throughout the field investigation, provide evidence that fractures act as conduits for deep infiltration, and that small fractures can be enlarged significantly by infiltration. The process can be explained as follows: small fractures form from subsurface explosions and regional tectonics; these fractures intercept stream channels and capture small quantities of runoff. Subsequent erosion of the fracture walls caused by the infiltrating water enlarges the fractures, which are then capable of capturing greater amounts of runoff. This process continues until subsurface passages become filled with sediment and material eroded from the fracture walls cannot be removed. The fractures then fill with sediment and eventually seal, but future subsurface explosions and tectonic stresses may reactivate them. During this process, potentially large quantities of runoff from the surrounding mesas will infiltrate to depths of at least several meters and possibly to groundwater. 


\section{POSSIBLE INFILTRATION BEHAVIOR}

Fracture infiltration in Yucca Flat is difficult to characterize because of its transient nature and the high lovel of uncertainty in fracture geometry and boundary conditions. The problem can be simplified by modelling the fracture as a vertical, planar fracture and assuming that moisture movement can be adequately characterized by one dimensional flow in the horizontal and vertical directions. Two possibilities might occur:

1. Water runs down the side of the fracture and is sucked horizontally into the wall of the fracture before it reaches the bottom, as shown in Figure 13 .

2. Water reaches the bottom of the fracture and fills or partially fills the fracture, resulting in both vertical and horizontal infiltration, as shown in Figure 14.

The amount of runoff entering the recharge zones identified in this study is unknown; no measurements of runoff to Yucca Flat have been made. Annual precipitation on Yucca Flat is estimated at 15 centimeters/year; for Pahute/Rainier mesas, the estimate rises to 23 centimeters/year (DOE, 1993). Daily precipitation measurements of rainfall on Rainier Mesa are available from the National Weather Service. The region that drains to the Carpetbag Fault zone has been estimated at greater than 64 square kilometers (McKinnis and Kao, 1993). French (1985) reports that the majority of storms monitored in the Nevada Test Site were less than 2 hours in duration and that these short storms contribute a significant portion of the total annual precipitation. It is likely that short, intense storms result in greater runoff than the longer, milder storms. Fractures that accept runoff will experience alternate periods of wetting and drying caused by periods of dry weather between storms.

The volume and rate of water that can infiltrate into a fracture during a two hour storm event can be estimated by considering an idealized fracture $2 \mathrm{~cm}$ wide and 30 meters deep filled with water. The water in the crack will wick out horizontally into the walls of the crack and infiltrate vertically down below the crack, as illustrated in Figure 15. Past horizontal infiltration experiments on sandy soils have shown the wetting front to advance about $30 \mathrm{~cm}$ from a source term held under zero hydraulic head for several hours (Bruce and Klute, 1956; Jackson, 1963; Kirkham and Feng, 1949; Nielsen et al., 1962; Smiles et al., 1978; Watson and Jones, 1982). If the average air filled porosity of the fracture walls is $30 \%$, then approximately $(0.3 \mathrm{~m})(30 \mathrm{~m})(0.3)(2)=5.4 \mathrm{~m}^{3}$ of 
water per meter crack length will be absorbed in the fracture walls by horizontal infiltration within the first several hours that the crack is filled. The amount of water that infiltrates vertically beneath the fracture in this time can be estimated from the vertical infiltration equation first derived by Green and Ampt (1911):

$$
t=\frac{\theta}{K}\left[L-(h+\Psi) \ln \left(\frac{L}{h+\Psi}+1\right)\right]
$$

where $\theta$ is the volumetric water content (volume of water per total volume of soil) in the region wetted by vertical infiltration, $L$ is the length of the wetted region, $h$ is the height of water in the crack $(30 \mathrm{~m}), \psi$ is the suction head at the wetting front, and $t$ is the time. Data on the alluvial soils of Frenchman Flat, the basin adjacent to Yucca Flat, can be used as estimates of soil properties in Yucca Flat. Laboratory experiments performed on samples of alluvium collected from boreholes drilled at the Radioactive Waste Management Site in Frenchman Flat, Area 5 , give saturated hydraulic conductivity values of about $10^{-3} \mathrm{~cm} / \mathrm{s}$ for alluvium with a porosity of aboult 0.3 to 0.4 . Water characteristic curves taken from the same set of samples suggest that $\Psi$ is less than $50 \mathrm{~cm}$, which is negligible compared to the 30 meter height of water in the crack. Extrapolating these values to the soils of Yucca Flat and assuming that $\theta=0.3$, equation 1 gives a wetting front that travels vertically down beneath the crack a distance of about 4 meters in two hours. This yields a volume of approximately $0.3(4 \mathrm{~m})(0.02 \mathrm{~m})=0.02 \mathrm{~m}^{3}$ per meter length of crack. The total volume infiltrated during two hours is then about $5.5 \mathrm{~m}^{3}$ per meter length of crack, with virtually all of the volume being stored within the walls of the fracture. If the crack continues to remain filled with water, then, according to equation 1 , water will infiltrate to a total depth of 60 meters (30 meters beneath the bottom of the crack) in 3 days, 130 meters in 19 days, and 1030 meters in 310 days.

These calculations are only rough estimates. The depth of vertical infiltration is overestimated, since the water will tend to wick out horizontally as it moves downwards, while the horizontal infiltration is underestimated, since the positive source water pressure is neglected. However, this simple exercise allows some quantitative grasp of possible infiltration behavior and illustrates that a fair amount of water can be quickly absorbed by a moderately large crack. 


\section{CONCLUSIONS}

A number of regions of Yucca Flat contain large fractures that appear to be accepting significant quantities of runoff and almost certainly result in deep infiltration. These fractures are dynamic features of a tectonically active region further disturbed by nuclear testing. Past and recent observations suggest that fractures in Yucca Flat:

- are capable of draining large quantities of water (e.g. Yucca Lake fracture; Carpetbag fault zone; U2gf northwest fractures; 1974 U2ef reserve pit).

- are enlarged by infiltrating water (e.g. 1987 U10 cb and 1988 U2gf fractures; 1974 U2ef reserve pit; fractures enlarged by trench interception).

- intercept stream channels and drainage pathways (e.g. Carpetbag fault zone; fractures enlarged by trench interception).

- $\quad$ tend to open under ponded water (e.g. 1974 U2ef reserve pit; Yucca Lake fracture).

- may not have surface expression (e.g. 1973 U2dw fracture) or may have mild surface expression while being open at depth (e.g. 1990 U2fe crack; fractures enlarged by trench interception).

- $\quad$ are dynamic; they open and seal, appear and disappear (e.g. Yucca fault fractures; Area 7 fractures that are no longer visible; Yucca Lake fracture).

Most of the investigations listed in Table 2 targeted fractures no deeper than about $\mathbf{2 0}$ meters, but none of the holes were drilled in the higher infiltration areas identified in the present field investigation. The possibility of deep and extensive fracturing within these regions, and possibly in other unexplored regions, raises concern for accelerated groundwater contamination.

The influence of fractures on infiltration in Yucca Flat depends upon the depth and frequency of fractures, the volume of water that flows into the fracture, and the mechanisms of infiltration. These topics all require further study. 


\section{RECOMMENDATIONS FOR FUTURE INFILTRATICN STUDIES}

Past and recent field investigations provide qualitative evidence that runoff from natural precipitation can be captured by fractures in alluvium on Yucca Flat. Quantitative information is necessary to test whether fractures serve as conduits for deep infiltration. Trenching across a fracture could provide information on the lateral extent and dynamics of moisture flow, while drilling several tens of meters deep would give some quantification of the possible vertical migration of intercepted storm water. Soil samples can be measured for the following analytes to provide information about soil moisture movement:

\section{Tritium, ${ }^{36} \mathrm{Cl}$ and ${ }^{14} \mathrm{C}$ :}

Moisture that has recharged the subsurface within the past forty years will exhibit elevated concentrations of tritium and ${ }^{36} \mathrm{Cl}$ associated with fallout of atmospheric testing from atomic weapons between 1952 to 1963. Evidence suggests that ${ }^{3} \mathrm{H}$ and ${ }^{36} \mathrm{Cl}$ enriched moisture has not penetrated below a depth of one or two meters in unfractured, undisturbed alluvium in Yucca Flat (Tyler, 1987; 1992). Post 1952 runoff preferentially flowing down fractures to depth and horizontally infiltrating into the fracture walls should reflect tritium and ${ }^{36} \mathrm{Cl}$ concentrations that are elevated relative to those of the background soil moisture. Locating the point at which this enriched moisture meets the original background soil moisture gives the length of the wetted region. If the date in which infiltration began is known, then the infiltration rate can be estimated. Tyler et al. (1992) found elevated tritium concentrations of about 125 $\mathrm{pCi} / \mathrm{l}$ in moisture that had apparently infiltrated after 1971 below a subsidence crater in Yucca Flat, while moisture in undisturbed alluvium nearby had tritium concentrations of iess than $16 \mathrm{pCi} /$.

Wetting, drying, and vapor transport would create a spread of tritium concentrations near the surface of the fracture wall and at the wetting front. Because ${ }^{36} \mathrm{Cl}$, unlike tritium, does not vaporize, a narrower band of concentrated ${ }^{36} \mathrm{Cl}$ within the spread of tritium concentrations should form. A subsequent wetting period would displace the layer of concentrated isotopes at the fracture wall further into the formation. Cycles of this process should result in a wetted zone dissected at regular intervals by bands of concentrated ${ }^{36} \mathrm{Cl}$ and variable tritium concentrations, as suggested by Figure 16.

Similarly, younger ${ }^{14} \mathrm{C}$ ages should be associated with recent wetting fronts. An age progression (younger to older) should be expected away from fracture surfaces. Regular variations may be perturbed by both 
radioactive decay and dissolution of older "dead" carbonate.

${ }^{87} \mathrm{Sr} /{ }^{86} \mathrm{Sr}:$

These isotopes will not be fractionated during transport of surface water and will carry an equilibrium signature of the host media. Previous work indicates that near-surface pedogenic vein carbonate is appreciably more radiogenic $(0.712)$ than waters derived from either Tertiary or Paleozoic aquifers (0.708-0.709). Besides utility as an infiltration marker, ${ }^{87} \mathrm{Sr}{ }^{86} \mathrm{Sr}$ ratios may be diagnostic of infiltrating waters which have acquired different soil or rock signatures during recharge.

\section{$\mathrm{Cl}, \mathrm{Br}$, and I}

The weight ratios of these ions can be used as indicators of saturated meteoric penetration, particularly if salts precipitate as concentric bands away from the fracture face, indicating separate wetting events. The biophillic nature of iodine relative to chlorine can be used to measure the infiltration effects in the root zone.

\section{Field Investigation}

Field work should be performed to investigate one dimensional infiltration in both the vertical and horizontal directions. The following actions are recommended:

1. Excavate a 4 meter deep trench across a large fracture to study the behavior of horizontal infiltration. Soil samples should be taken along the trench wall on both sides of the fracture at $15 \mathrm{~cm}$ intervals to a distance 4 meters away from the fracture. This procedure should be performed at depths of 2,3 , and 4 meters.

2. Investigate the extent of vertical infiltration and fracture depth by slant drilling a standard $120 \mathrm{ft}$ deep augur hole across a large fracture that shows clear signs of infiltration; collect cuttings and core samples at meter intervals during drilling.

The collected samples should be measured for the analytes described above. 
Possible Locations for Field Work:

The fracture(s) chosen for the proposed field investigations should have the following characteristics:

- Evidence of significant infiltration.

- Available runoff/infiltration history.

- Formation of a measurable wetted region with clear isotope signatures.

Two locations that best satisfy these requirements are:

- The southern Carpetbag fault scarp where breached by eastwards draining stream channels (Area 2). Channels existed prior to the formation of the scarp and is currently active. It can reasonably be assumed that the fault first began accepting runoff immediately after the formation of the scarp in December of 1970, and that the intercepted stream has been a source of inflow to the fault since this time. Twenty three years of periodic infiltration should provide sufficient information to characterize infiltration behavior.

- Fractures at the northern extreme of the Carpetbag fault scarp. These fractures began accepting large amounts of runoff during the winter of 1992-1993; laige amounts of erosion occurred during this time, and the fractures were greatly enlarged. Investigations in both the vertical and horizontal directions would be insightful.

The proposed field investigation will quantify whether deep infiltration is occurring at Yucca Flat and can provide an approximate picture of the mechanisms of moisture movement. If the results prove significant, then a controlled laboratory study should be performed to gain insight into the infiltration behavior under well-defined conditions.

\section{Acknowledgements}

This research was performed under appointment to the Graduate Fellowships for Environmental Restoration and Waste Management administered by Oak Ridge Institute for Science and Education for the U.S. Department of Energy. The Hydrologic Resources Management Program (Greg Nimz - LLNL Program Manager) provided funding for much of the field work. Harry Covington of the USGS, James R. Hunt of 
the University of California at Berkeley and Susan Freeman of the Los Alamos National Laboratory provided useful comments and suggestions in the development of this work. 
TABLE 1: Hydrostratigraphic units at the Nevada Test Site

(after Winograd and Thordarson, 1975 and DOE, 1993)

\begin{tabular}{|c|c|c|c|c|}
\hline $\begin{array}{c}\text { Geologic } \\
\text { Time } \\
\text { Period }\end{array}$ & $\begin{array}{c}\text { Regional Geologic } \\
\text { Unit }\end{array}$ & $\begin{array}{c}\text { Hydrostratigraphic } \\
\text { Unit }\end{array}$ & $\begin{array}{c}\text { Transmissivity } \\
\mathrm{m}^{2} / \mathrm{d}\end{array}$ & $\begin{array}{c}\text { Permeability } \\
\mathrm{m} / \mathrm{d}\end{array}$ \\
\hline \multirow[t]{6}{*}{ Cenozoic } & alluvium & alluvial aquifer & 10 to 500 & 0.2 to 3 \\
\hline & $\begin{array}{l}\text { volcanics of Fortymile } \\
\text { Canyon }\end{array}$ & lava-flow aquifer & 7 to 150 & - \\
\hline & $\begin{array}{l}\text { Timber Mountain } \\
\text { Group } \\
\text { Paintbrush Group }\end{array}$ & welded-tuff aquifer & 2.5 to 1500 & 0.1 \\
\hline & Bedded tuff & bedded tuff aquifer & 3 to 15 & - \\
\hline & Wahmonie Formation & lava-flow aquitard & $<8$ & - \\
\hline & Indian Trail Formation & tuff aquitard & 2 & $3 \times 10^{-6}$ to $3 \times 10^{-1}$ \\
\hline Mesozoic & granitic stocks & minor aquitard & - & - \\
\hline \multirow[t]{3}{*}{ Paleozolc } & Bird Spring Formation & $\begin{array}{l}\text { upper carbonate } \\
\text { aquifer }\end{array}$ & 15 to 1500 & - \\
\hline & Eleana Formation & $\begin{array}{l}\text { upper clastic } \\
\text { aquitard (Eleana } \\
\text { confining unit) }\end{array}$ & $<8$ & - \\
\hline & $\begin{array}{l}\text { Guilmette Formation } \\
\text { Simonson Dolomite } \\
\text { Sevy Dolomite } \\
\text { Laketown Dolomite } \\
\text { Ely Springs Dolomite } \\
\text { Eureka Quartzite } \\
\text { Pogonip Group } \\
\text { Nopah Formation } \\
\text { Bonanza King } \\
\text { Formation } \\
\text { Carrera Formation }\end{array}$ & $\begin{array}{l}\text { lower carbonate } \\
\text { aquifer }\end{array}$ & 15 to 15000 & - \\
\hline $\begin{array}{l}\text { Paleozoic } \\
\text { and Pre- } \\
\text { Cambrian }\end{array}$ & $\begin{array}{l}\text { Zabriskie Quartzite } \\
\text { Vivod Canyon } \\
\text { Formation } \\
\text { Stirling Quartzite } \\
\text { Johnnie Formation }\end{array}$ & $\begin{array}{l}\text { lower clastic } \\
\text { confining unit }\end{array}$ & $<15$ & - \\
\hline
\end{tabular}


TABLE 2: Observations of fractures recorded in memos (McKinnis and Kao, 1993)

\begin{tabular}{|c|c|c|c|c|c|}
\hline DATE & LOCATION & $\begin{array}{l}\text { MAX. } \\
\text { DEPTH } \\
(m)\end{array}$ & $\begin{array}{l}\text { MAX. } \\
\text { WIDTH } \\
(\mathrm{cm})\end{array}$ & TYPE & COMMENTS \\
\hline 1964 & U9cb hole & $>30$ & 10 & linear EW & $\begin{array}{l}\text { occured during drilling; drilling fluid } \\
\text { erupted. }\end{array}$ \\
\hline 1966 & U2m site & $?$ & $?$ & circumf. & $\begin{array}{l}\text { Underground room investigation. } \\
\text { No fractures seen at depth }\end{array}$ \\
\hline 1973 & U2dw hole & 18 & $?$ & $?$ & $\begin{array}{l}\text { Not visible at surface. } \\
\text { first seen at } 1.8 \mathrm{~m} \text { depth }\end{array}$ \\
\hline 1973 & hole $75 \mathrm{~m}$ NE of U2dv & 4.6 & $?$ & circumf. & took water to $3.7 \mathrm{~m}$ depth \\
\hline 1973 & U2ed hole & 14 & $?$ & linear NE & narrowed with depth \\
\hline$?$ & $\begin{array}{l}\text { U2v } \\
\text { U2ec } \\
\text { U2e日 } \\
\text { U2eg } \\
\text { U2dv }\end{array}$ & $<20$ & $?$ & $?$ & small below $5 \mathrm{~m}$ depth \\
\hline 1974 & hole $33.5 \mathrm{~m} \mathrm{SW}$ of U2aw & $>36$ & $30-45$ & linear $N E$ & narrowed with depth \\
\hline 1974 & hole $91 \mathrm{~m} \mathrm{~N}$ of U2aw & 21.3 & $30-45$ & linear NE & narrowed with depth \\
\hline 1974 & U2ef reserve pit & $?$ & $>30$ & $?$ & $\begin{array}{l}\text { drained reserve pit; widened with } \\
\text { drainage }\end{array}$ \\
\hline 1974 & hole $244 \mathrm{~m}$ E-NE of U2dr & 23 & $?$ & circumf. & $\begin{array}{l}\text { wide at surface, narrowed with } \\
\text { depth }\end{array}$ \\
\hline 1977 & hole $183 \mathrm{~m} \mathrm{~N}$ of U2ao & 16 & 20 & circumf. & \\
\hline 1979 & $\begin{array}{l}4 \text { holes } 150 \mathrm{~m} \text { E-SE of } \\
\text { U10bg }\end{array}$ & $<10$ & $?$ & NS & \\
\hline$?$ & hole near U2co & $>9$ & $?$ & circumf. & downhole photos \\
\hline 1987 & hole NW of U10cb & 2.13 & 10 & $?$ & widened after rainstorm \\
\hline 1988 & site S-SW of U2gf & $?$ & 30 & linear $N E$ & $\begin{array}{l}\text { split Rainier Mesa Road; captured } \\
\text { storm runoff }\end{array}$ \\
\hline 1989 & hole $358 \mathrm{~m} \mathrm{SW}$ of U2fe & $?$ & 30 & linear NE & $\begin{array}{l}\text { widened with depth to } 30 \mathrm{~cm} \text { at } 9 \mathrm{~m} \\
\text { depth }\end{array}$ \\
\hline 1990 & hole $S$ of U4av & 13.5 & $<0.2$ & $?$ & \\
\hline 1990 & hole U2gj & 15.5 & $?$ & $?$ & $\begin{array}{l}\text { initially thought crack }<6 \mathrm{~m} \text { deep; } \\
\text { widening hole diameter exposed } \\
\text { fracture at greater depth. }\end{array}$ \\
\hline
\end{tabular}




\section{REFERENCES}

Barnes, $H$, and F. G. Poole, 1968, Regional thrust-fault system in Nevada Test Site and Vicinity, in Nevada Test Site, Geological Society of America Memolr 110, E. B. Eckel, ed., pp. 233-238.

Barosh, P. J., 1968, Relationships of explosion-produced fracture patterns to geologic structure in Yucca Flat, Nevada Test Site, in Nevada Test Site, Geological Soclety of America Memoir 110, E. B. Eckel, ed., pp. 199-217.

Bruce, R. R. and A. Klute, 1956, The measurement of soil moisture diffusivity, Soil Science Soclety of America, Proceedings, Vol. 20, No. 4, pp. 458-462.

Carr, W. J., 1965, Preliminary Results of Subsurface Investigation of Fractures in Yucca Flat, Nevada Test Site, Technical Letter Yucca-57.

Carr, W. J., 1974, Summary of Tectonic and Structural Evidence for Stress Orientation at the Nevada Test Site, USGS Open-file Report 74-176.

Dickey, D. D., 1968, Fault displacement as a result of underground nuclear explosions, in Nevada Test Site, Geological Society of America Memoir 110, E. B. Eckel, ed., pp. 219-232.

DOE. See U. S. Department of Energy.

Doty, G. C., and F. E. Rush, 1985, Inflow to a Crack in Playa Deposits of Yucca Lake, Nevada Test Site, Nye County, Nevada, USGS Water Resources Investigations Report 84-4296.

Ekren, E. G., 1968, Geologic setting of Nevada Test Site and Nellis Air Force Range, in Nevada Test Site, Geological Society of America Memoir 110, E. B. Eckel, ed., pp. 11-20.

French, R. H., 1985, Additional Intensity Duration Analyses and Design Hyetograph Parameters for Various Precipitation Stations on the Nevada Test Site, Nevada, Water Resources Center, Desert Research Institute, University of Nevada System, Las Vegas, Nevada, Publication \# 45043.

Garcia, M. and J. A. Sharps, 1986, Results of Recent Mapping Along the Carpetbag Fault System, Yucca Flat, Nevada, USGS Open-File Report 86-449.

Gillson, R. G., 1993, Analysis of Borehole Elongation in Yucca Flat and Pahute Mesa, Nevada Test Site, Nevada, Using the Digital Downhole Surveyor, M.S. thesis, University of Arkansas. 
Green, W. H. and G. A. Ampt, 1911, Studies on soil physics, Part

1. The flow of air and water through soils, J. Agric. Sci., 4, pp. 1-24.

Hindrichs, E. N., 1968, Geologic structure of Yucca Flat Area, Nevada, in Nevada Test Site, Geological Society of America Memoir 110, E. B. Eckel, ed., pp. 239-246.

Jackson, R. D., 1963, Temperature and soil-water diffusivity relations, Soil Science Soclety of America Proceedings, Vol. 27, No. 4, pp. 363-366.

Kirkham, D. and C. L. Feng, 1949, Some tests of the diffusion theory, and laws of capillary flow, in soils, Soll Science, Vol. 67, pp. 29-40.

Knauss, K. G., 1981, Dating Fault Associated Quaternary Material from the Nevada Test Site Using Uranium-Series Methods, Lawrence Livermore National Laboratory, Livermore, California, UCRL 53231.

McKinnis, W. B. and C. S. Kao, 1993, Potential for Infiltration Through Fractured Alluvium in Yucca Flat of the Nevada Test Slte: Preliminary Field Investigation, Unpublished LLNL Draft Report.

Nielsen, D. R., J. W. Biggar, and J. M. Davidson, 1962, Experimental consideration of diffusion analysis in unsaturated flow problems, Soil Science Society of America, Proceedings, Vol. 26, No. 2, pp. 107-111.

Nilson, R. H., P. L. Lagus, W. B. McKinnis, J. R. Hearst, N. R. Burkhard, and C. F. Smith, 1991, Field measurements of tracer gas transport induced by barometric pumping, 6th Symposium on Containment of Underground Nuclear Explosions, Sept. 24-27, 1991, Reno, Nevada.

Smiles, D. E., J. R. Philip, J. H. Knight, and D. E. Elrick, 1978, Hydrodynamic dispersion during absorption of water by soil, Soll Science Society of America Journal, Vol. 42, pp. 229-236.

Spengler, R. W., and V. M. Glanzman, 1980, Review of Geology and Material Property Data in Shallow Alluvium, Eastern Area 2, Nevada Test Site, U.S. Geological Survey Technical Letter NTS-262.

Sweeney, J. J., 1983, Characteristics of the Eleana Formation, Nevada Test Site, Lawrence Livermore National Laboratory, Livermore, CA, UCRL-53445, 68 p.

Tyler, S. W., W. A. McKay, and T. M. Mihevc, 1992, Assessment of soil moisture movement in nuclear subsidence craters, Journal of Hydrology, Vol. 139, pp. 159-181. 
Tyler, S. W., 1987, Review of soil moisture flux studies at the Nevada Test Site, Nye County, Nevada, Water Resources Center, Desert Research Institute, University of Nevada System, Publication \# 45058.

U. S. Department of Energy, Nevada Operations Office, 1993, Underground Test Area Remedial Investigation and Feasibility Study Work Plan, Nevada Test Site, Nevada, Draft Report, DOE/NV/10972- 67, Las Vegas, Nevada.

Wagoner, J. L., 1980, memo to H. L. McKague regarding trench logs for U2fe, KTP 80-13, June 24.

Watson, K. K. and M. J. Jones, 1982, Hydrodynamic dispersion during absorption in a fine sand 1 . the constant concentration case, Water Resources Research, Vol. 18, No. 1, pp. 91-100.

Williams, W. P., W. L. Emerick, R. E. Davis, and R. P. Snyder, 1963, U.S. Geological Survey investigations in Yucca Flat, Nevada Test Site, part C. The underground test media of Yucca Flat, U.S. Geological Survey Technical Letter NTS-45.

Winograd, I. J. and W. Thordarson, 1968, Structural control of ground-water movement in miogeosynclinal rocks of south-central Nevada, in Nevada Test Site, Geological Society of America Memolr 110, E. B. Eckel, ed., pp. 35-48.

Winograd, I. J. and W. Thordarson, U.S. Geological Survey, 1975, Hydrogeologic and hydrochemical framework, South-Central Great Basin, Nevada-California, with special reference to the Nevada Test Site, U.S. Geological Survey Professional Paper 712-C, Washington, DC. 


\section{FIGURE CAPTIONS}

Figure 1. Map showing the Nevada Test Site and regional geologic and Physiographic features (from Ekren, 1968).

Figure 2. Location of major thrust zones in Paleozoic rocks in the Nevada Test Site area. (from Sweeney, 1983)

Figure 3. Geologic map of the Nevada Test Site showing location of Yucca and Carpetbag faults (from Garcia and Sharps, 1986)

Figure 4. Location of announced underground nuclear tests (from DOE, 1993).

Figure 5. Photograph looking northeast across Rainier Mesa Road (Area 2) of a storm-induced fracture. Substantive run-off from a summer thunderstorm was recharged by this feature.

Figure 6. View looking south across Yucca Lake playa (Area 6) of tunnel structure with fracture propogating in the distance.

Figure 7. Fractures and topography of Yucca Lake playa (from Doty and Rush, 1985).

Figure 8. Location of playas having fractures similar to those of Yucca Lake playa. Playas are numbered 1 through 4. (from Carr, 1974).

Figure 9. Simplified map of the Carpetbag Fault system (from Garcia and Sharps, 1986).

Figure 10. View looking south across northern Carpetbag fault scarp (Area 2). Note development of graben structure to the east as well as fracture splays associated with the offset scarp.

Figure 11. View of trench face cut across southern Carpetbag fault (Area 2). Note caliche in-fill along fracture paleo-surfaces. Centimeter scale (left) - inch scale (right).

Figure 12. View looking north in Area 2 of dynamic fracture system associated with the northern Carpetbag fault. Note recent unconsolidated sediment in bottom of the structure as well as total dimension of this feature. Geologist for scale. 
Figure 13. Possible infiltration behavior into an idealized fracture: runoff enters the formation before the bottom of the fracture is reached.

Figure 14. Possible infiltration behavior into an idealized fracture: runoff fills or partially fills the fracture, resulting in both vertical and horizontal infiltration.

Figure 15. Schematic diagram of infiltration from a model fracture filled with runoff water. $h=$ height of water in fracture, $L=$ length of wetted region.

Figure 16. The region of the soil profile affected by cycles of wetting, drying, and vapor transport should have bands of concentrated ${ }^{36} \mathrm{Cl}$ within zones of tritium dispersed by vapor transport. 


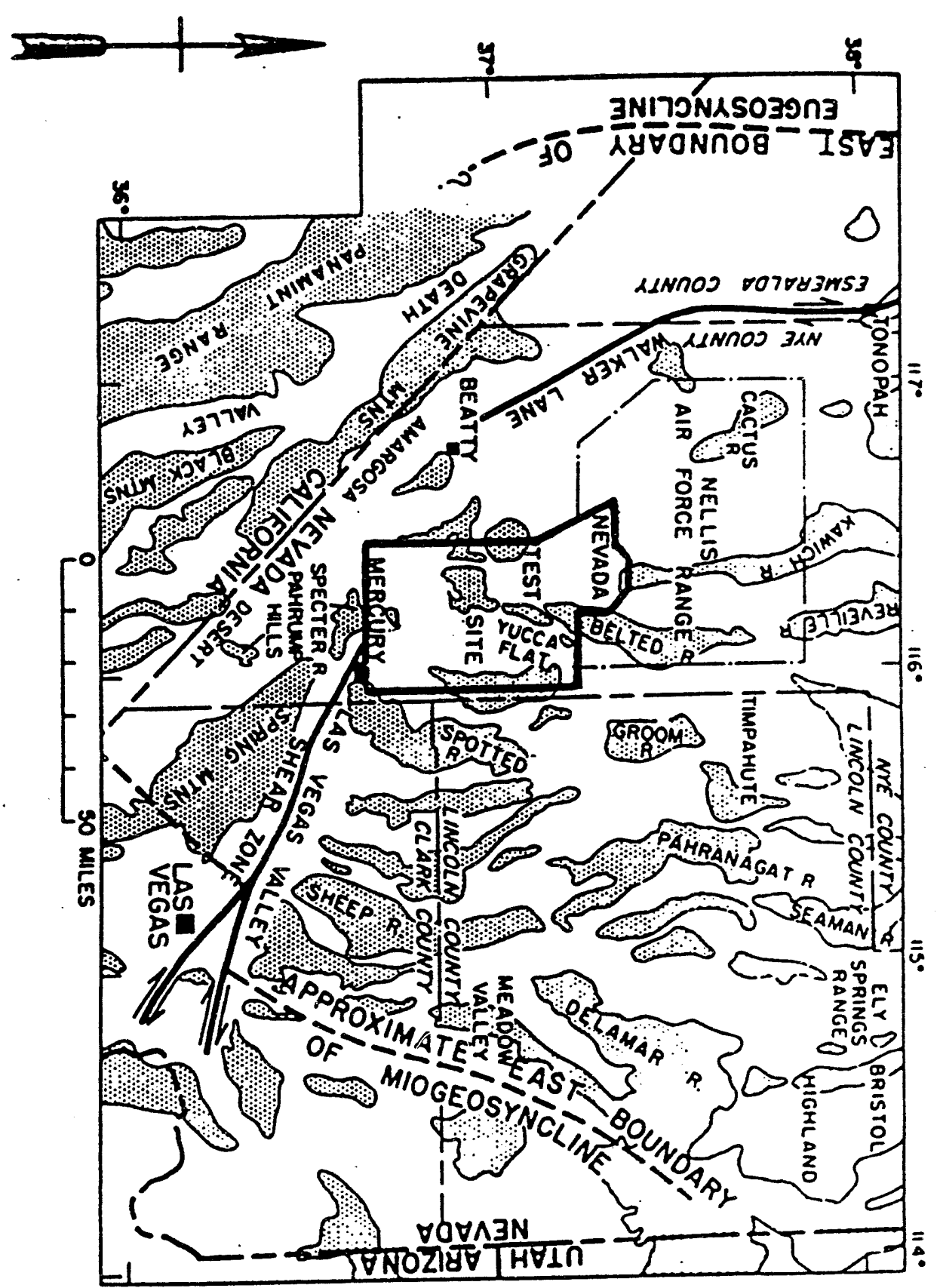




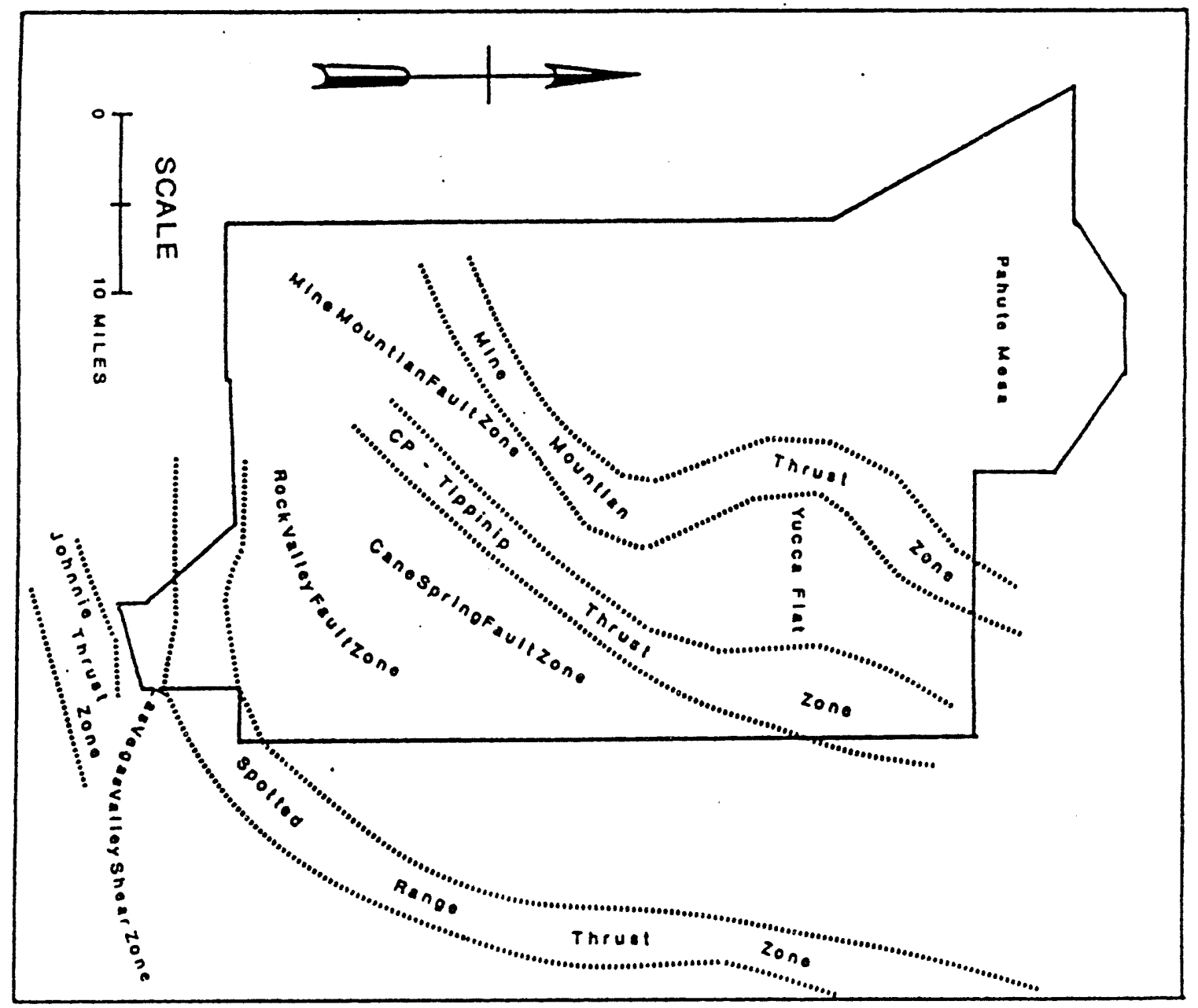




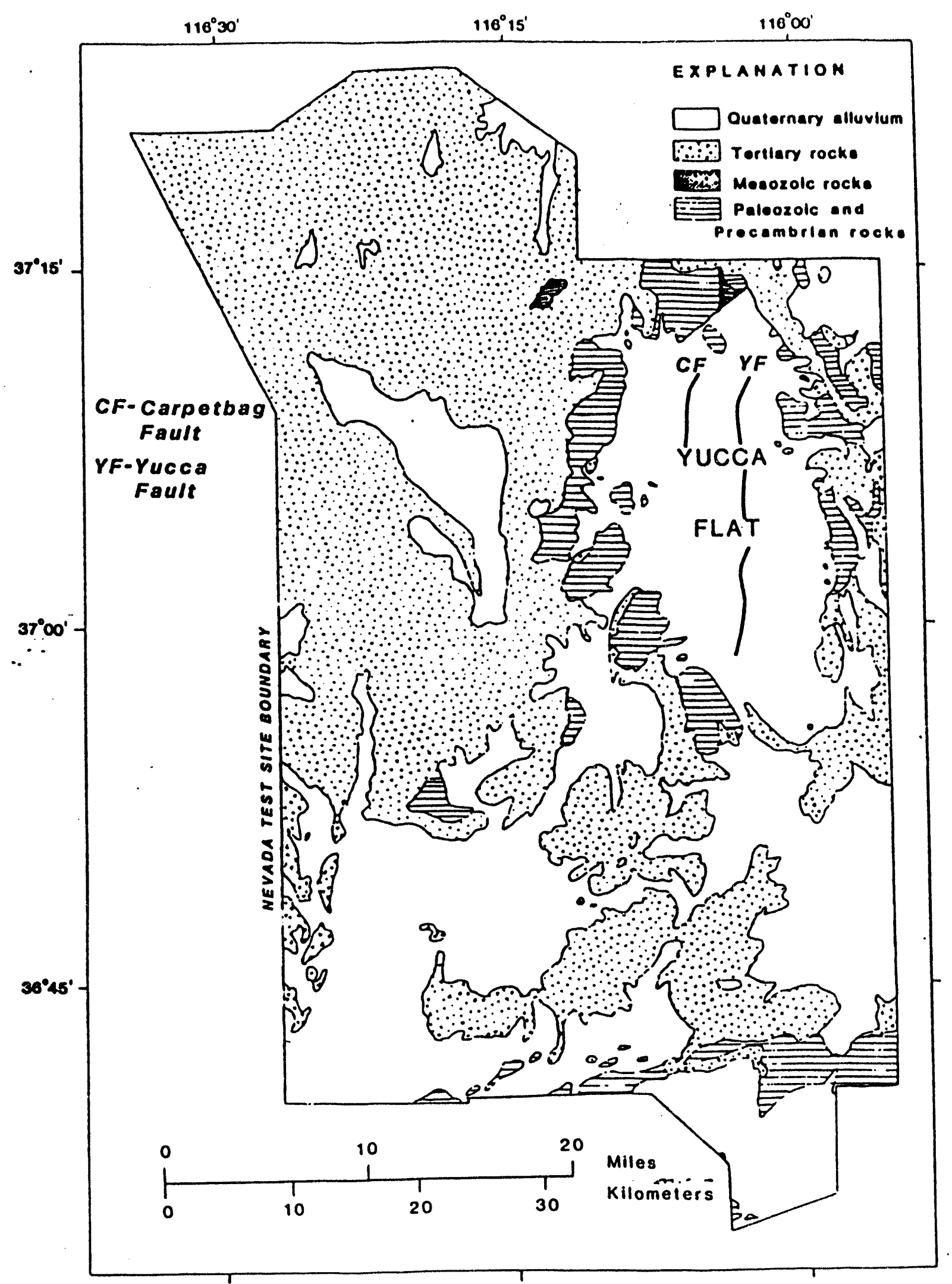

Figure 3 


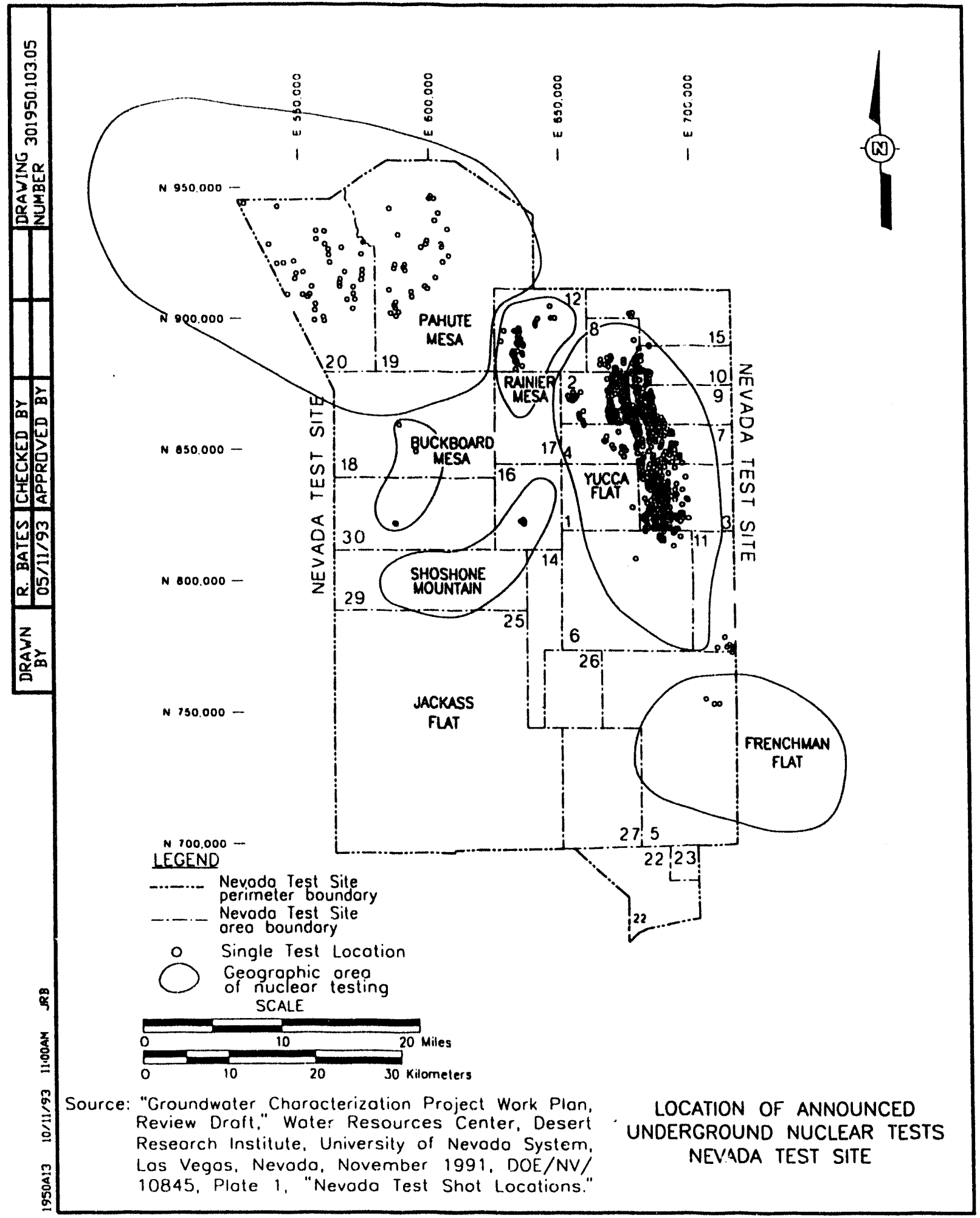

Figure 4 
G $\operatorname{axn} 6 !\rfloor$

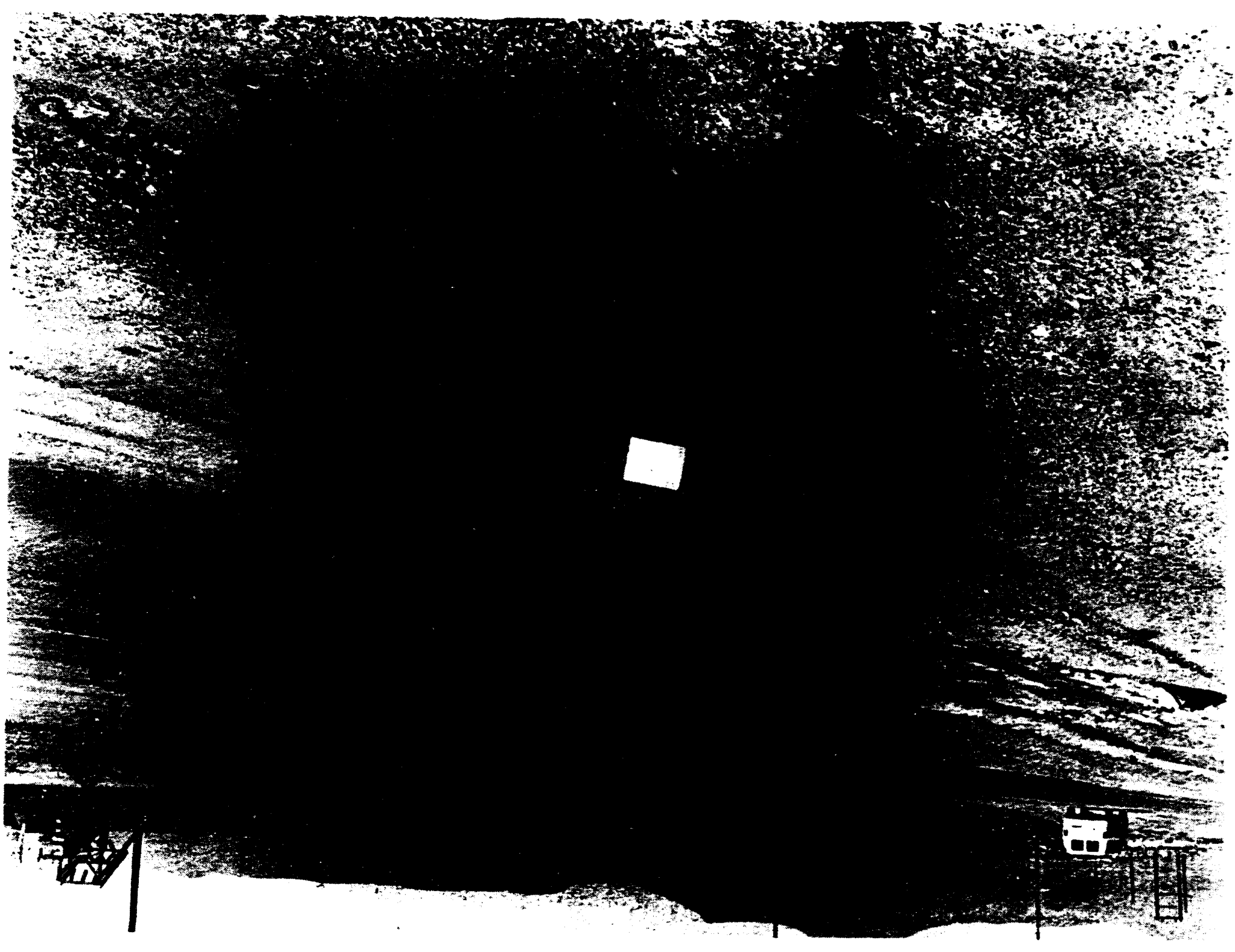




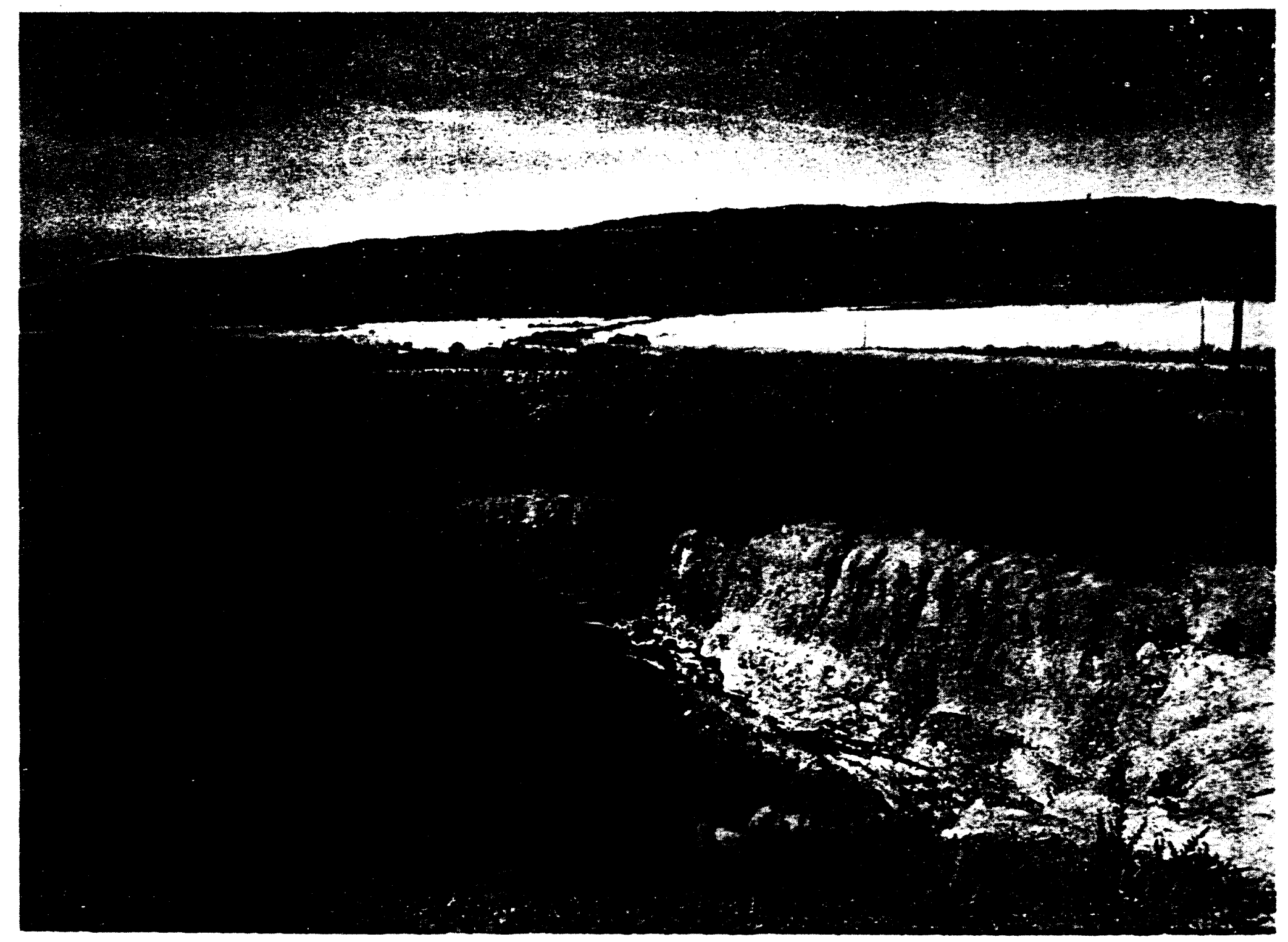

Figure 6 


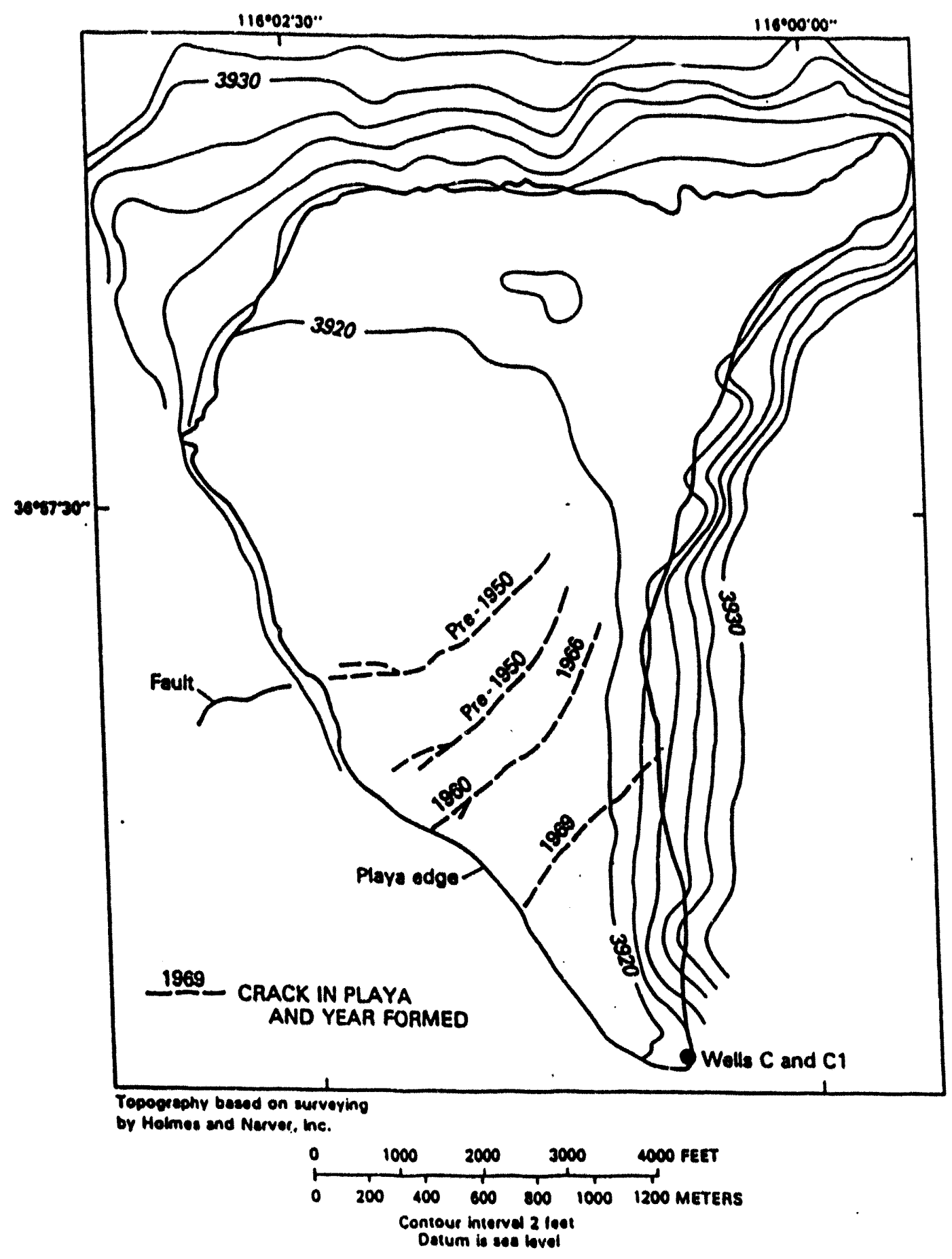

Figure 7 


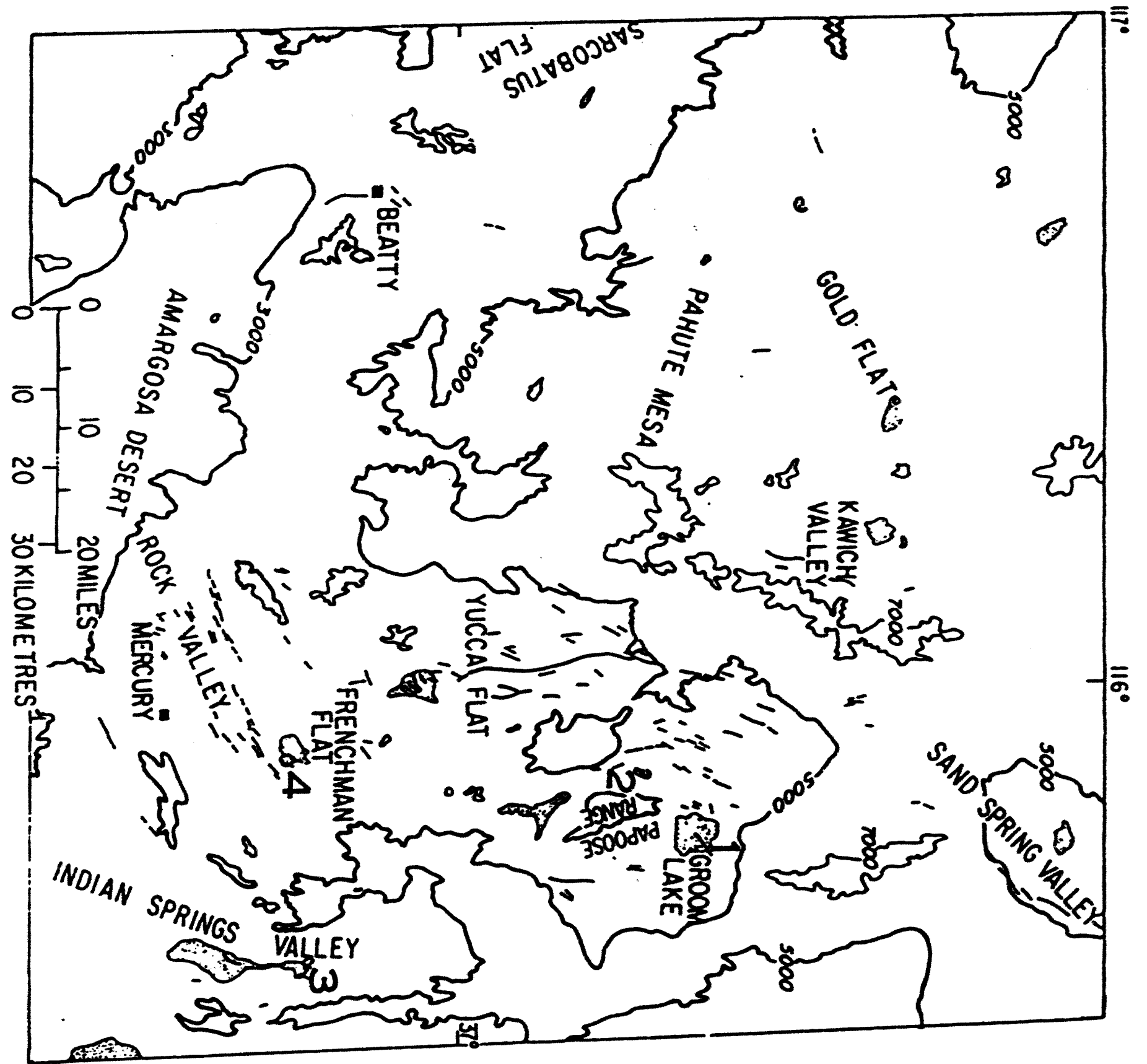




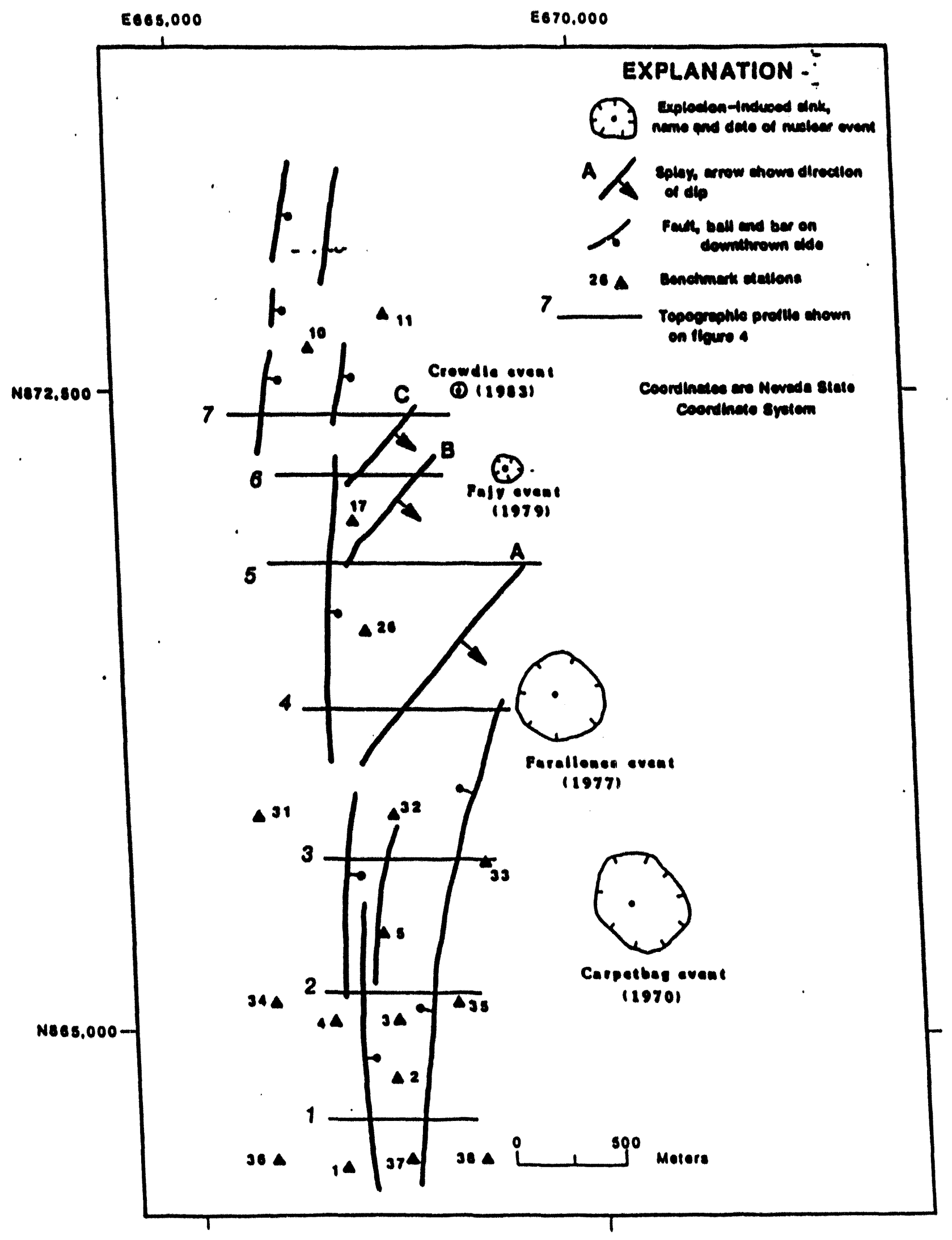

Figure 9 


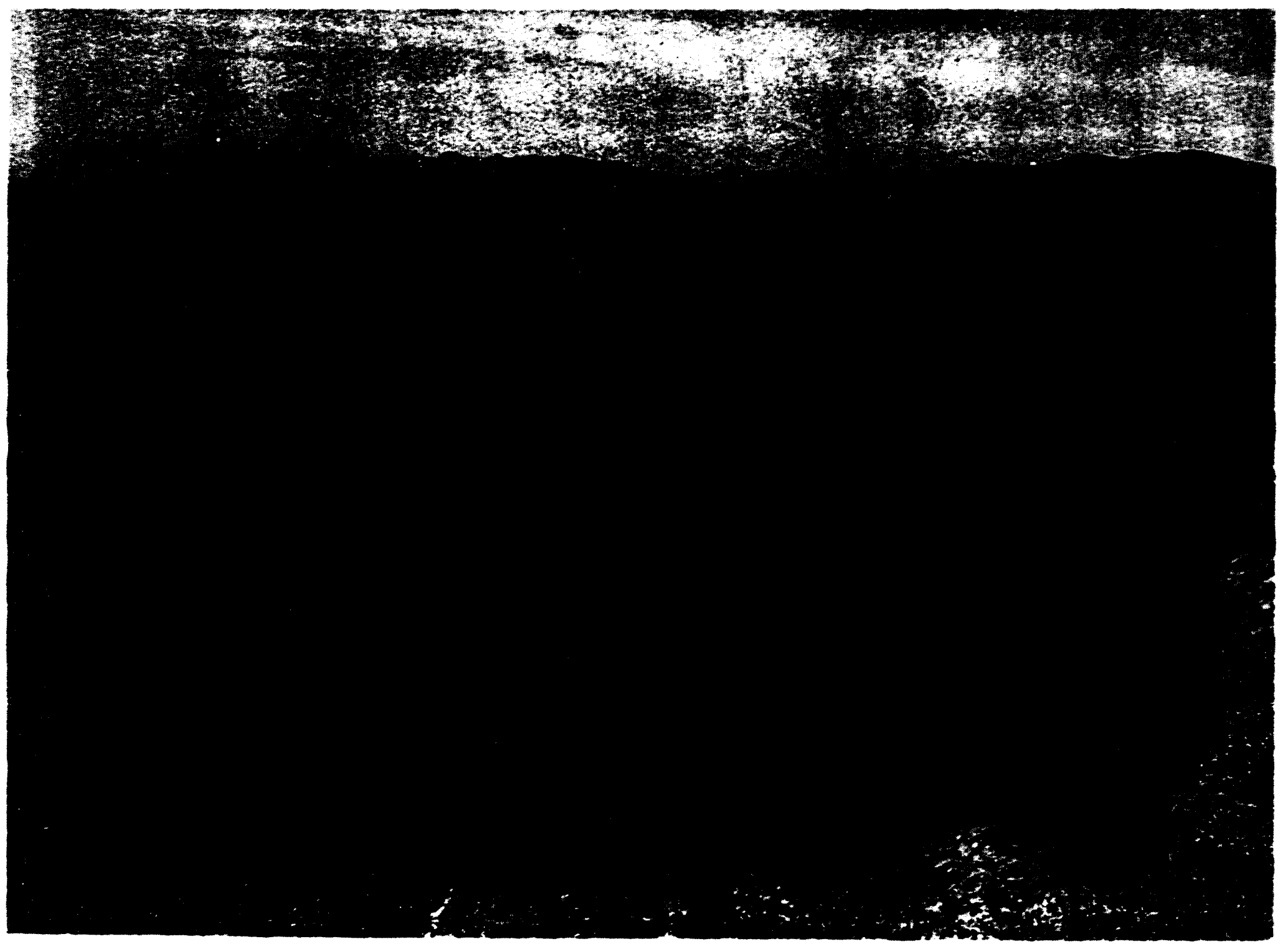

Figure 10 


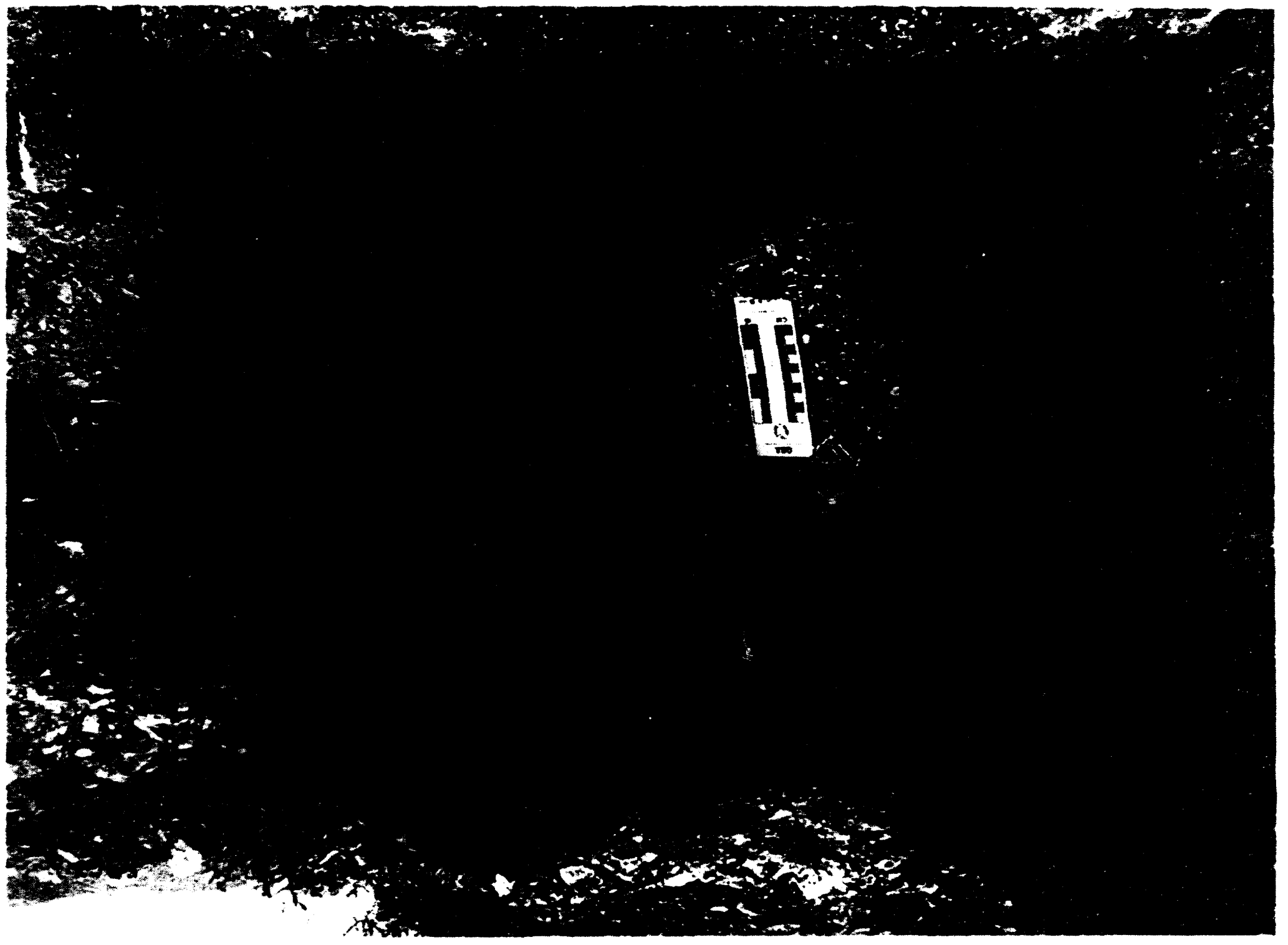




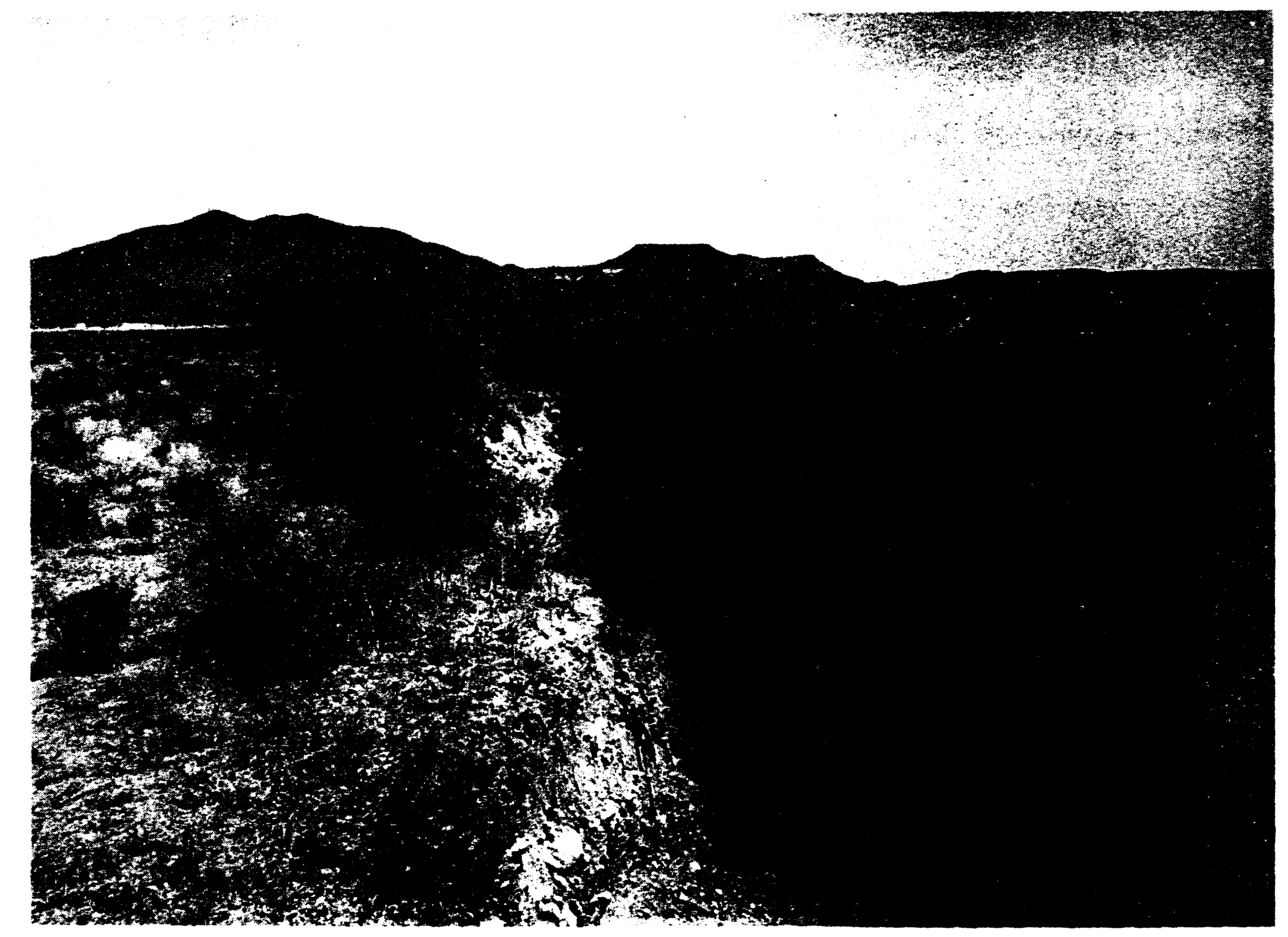

Figure 12 


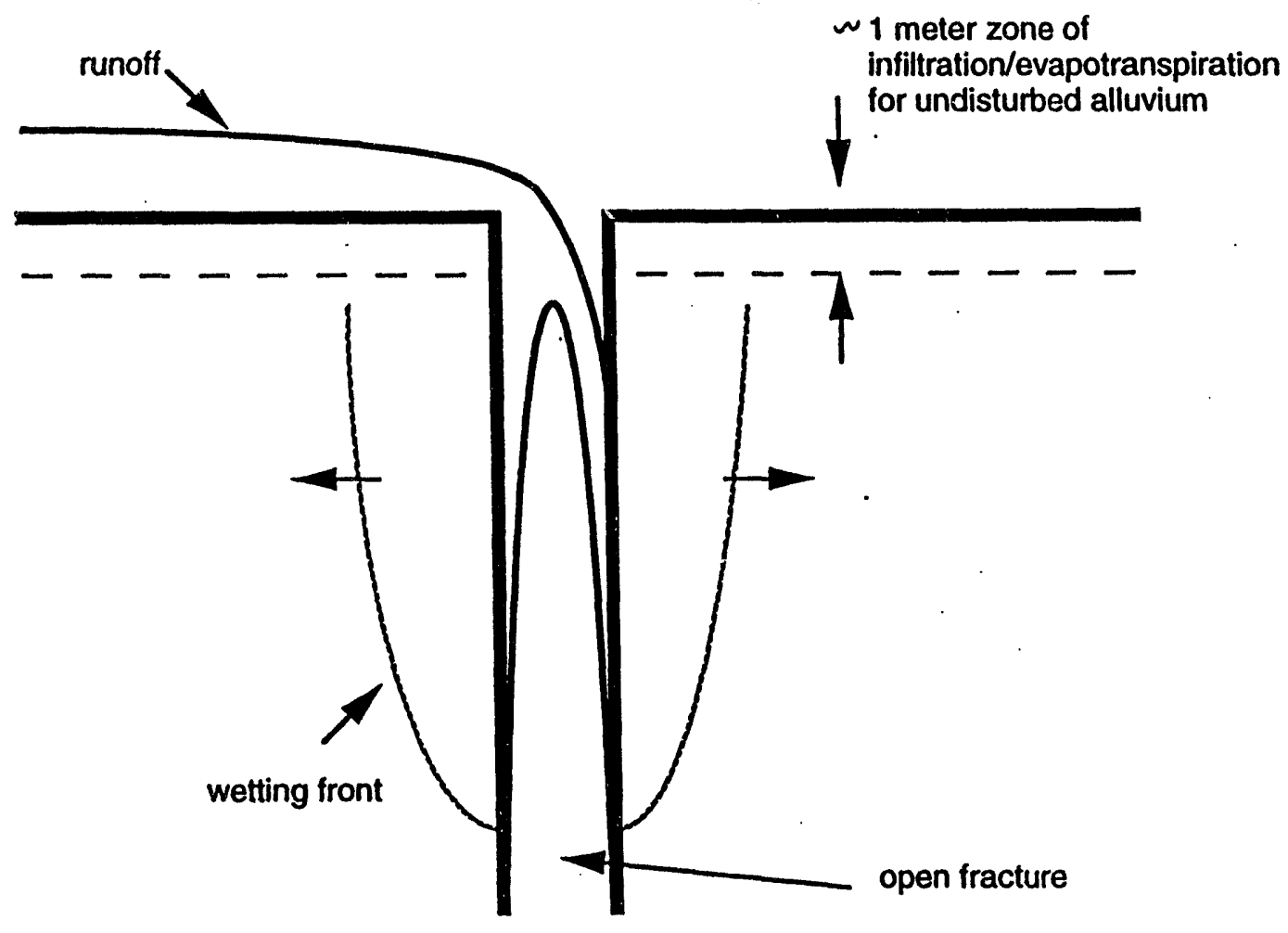

Figure 13 


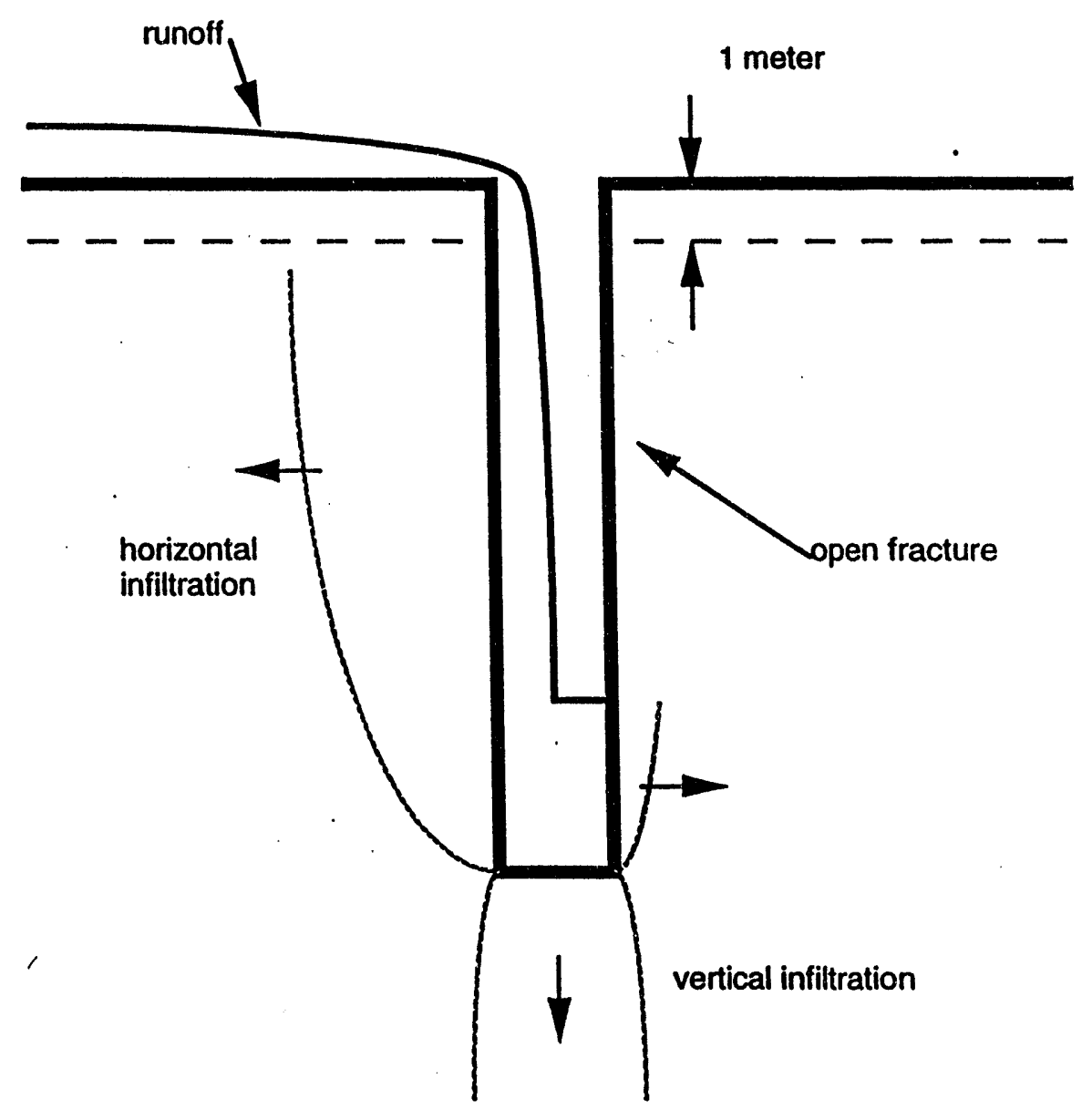

Figure 14 


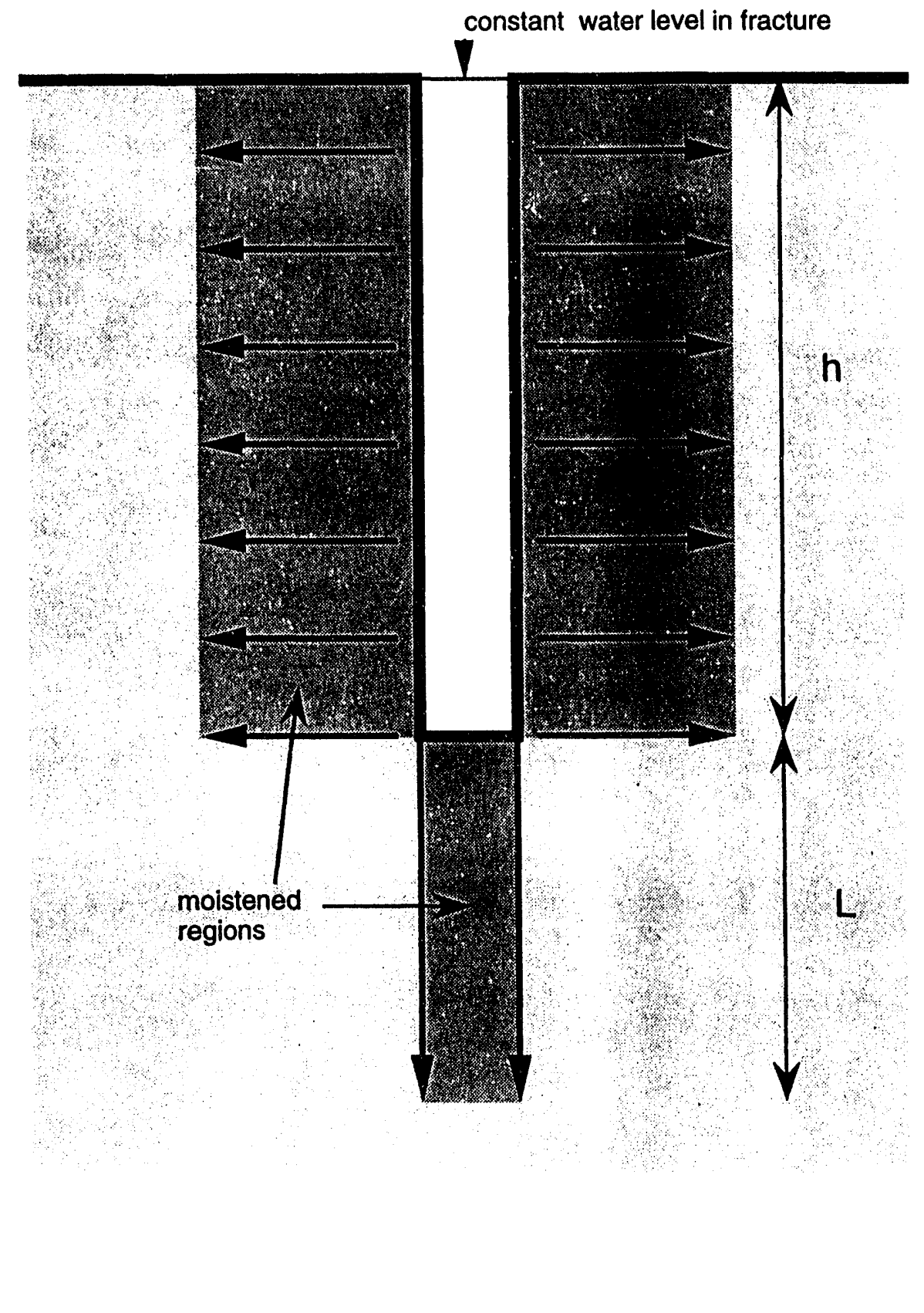

Figure 15 
$\sim 1$ meter zone of infiltration/evapotranspiration

1 for undisturbed alluvium

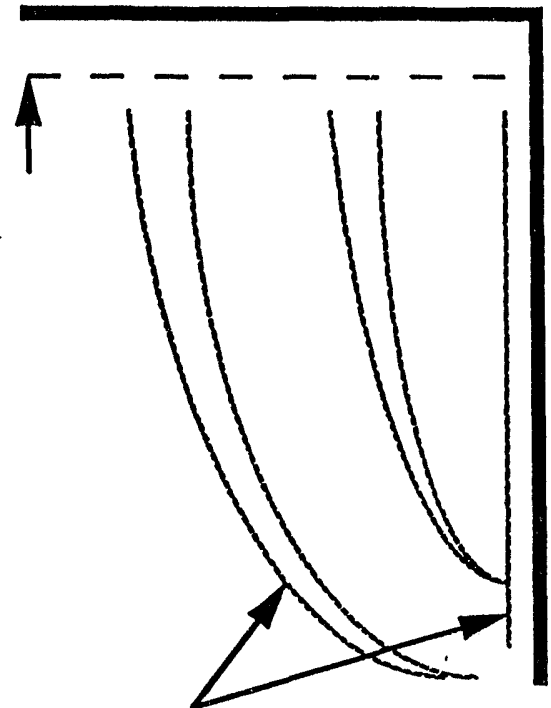

bands of concentrated chlorine-36 and varying tritium levels

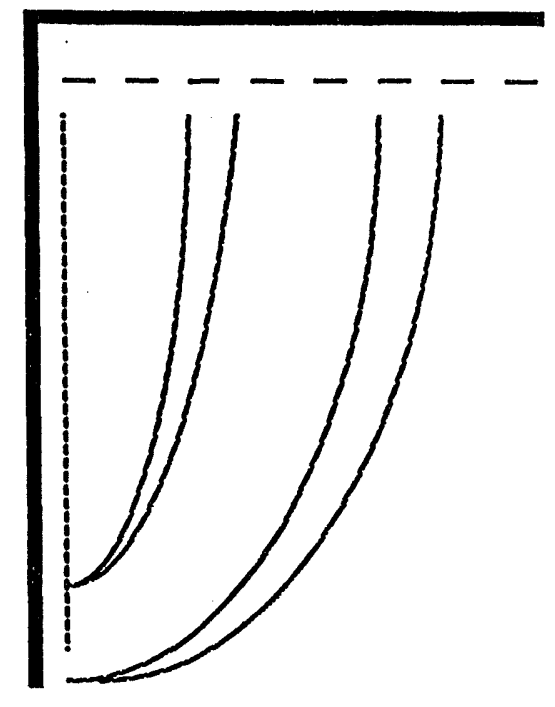



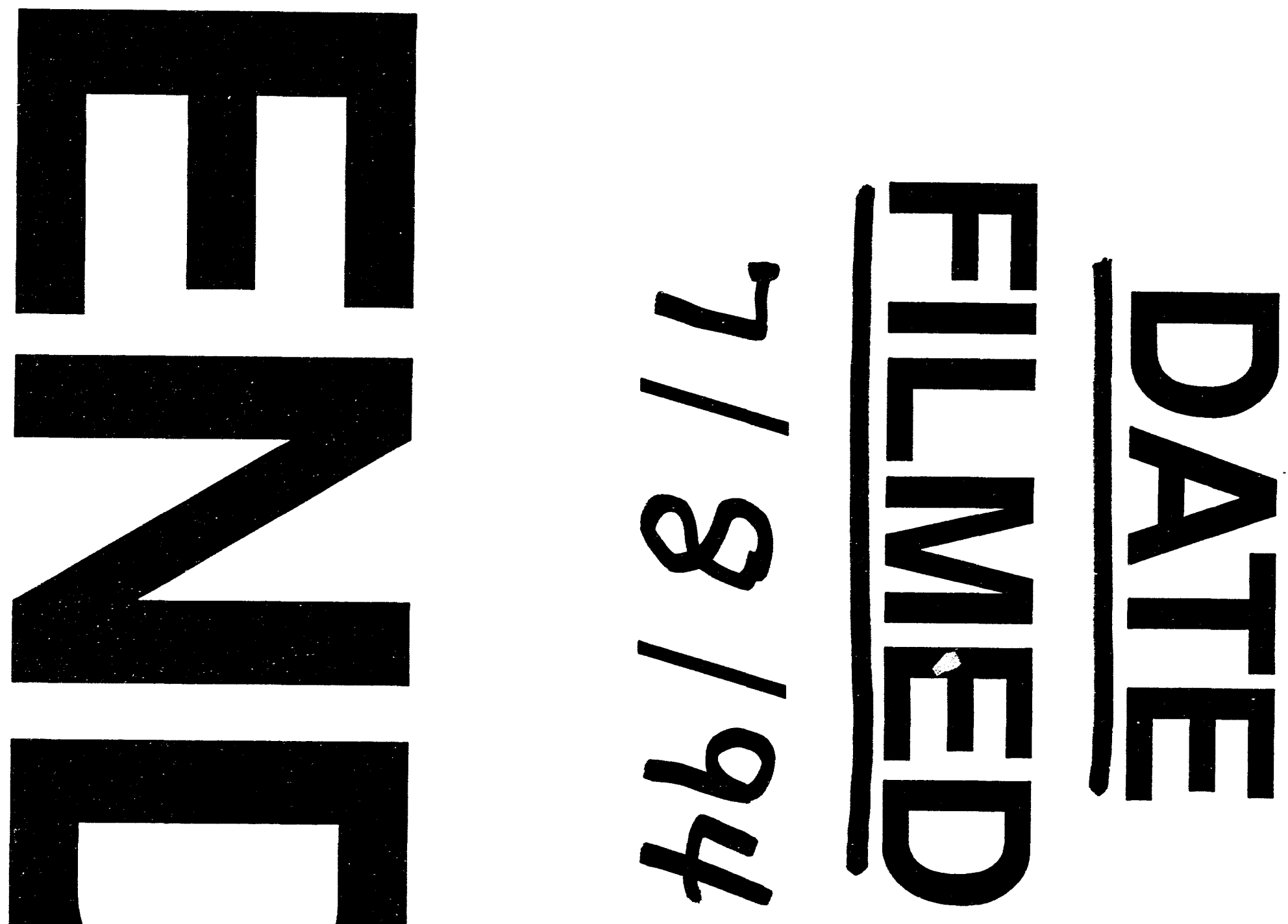
